\title{
Nucleic Acid-Based Methods to Identify, Detect and Type Pathogenic Bacteria Occurring in Milk and Dairy Products
}

\author{
Vincenzina Fusco and Grazia Marina Quero \\ Additional information is available at the end of the chapter
}

http://dx.doi.org/10.5772/49937

\section{Introduction}

Foodborne illnesses caused by pathogenic microorganisms, including bacteria, viruses and parasites are among the most serious public health concerns worldwide. A recent document of the Center for Disease Control and Prevention (CDC) estimates that each year 1 out of 6 American (or 48 million people) get sick, 128,000 are hospitalized and 3,000 die due to foodborne diseases, with Norovirus, nontyphoidal Salmonella, Clostridium perfringens, Campylobacter spp. and Staphylococcus (S.) aureus being the top five pathogens causing domestically acquired foodborne illnesses [1]. In the European Union, during 2009, 5,550 food-borne outbreaks occurred, mainly due to Salmonella, viruses and bacterial toxins, causing 48,964 human cases, 4,356 hospitalisations and 46 deaths [2]. Bacteria such as Salmonella spp., Campylobacter spp., Listeria (L.) monocytogenes, Escherichia (E.) coli O157:H7 and (S.) aureus have generally been identified as etiologic agents of most food-borne illnesses, with milk and its derivatives products among the most frequently involved food matrices. Moreover, although "less hazardous", these pathogens are a constant threat to the agro-food security, since they can be used to contaminate the environment, crops and animals, causing heavy damage to public health, agriculture and environment [3].

Traditionally, cultivation methods, ranging from plate counting to biochemical characterization, have been used to monitor pathogenic microorganisms in foods. However, these methodologies are labour-intensive and time-consuming, requiring from days to weeks to get results, with the consequence that products are often released for sale before the microbiological results become available. Moreover, these traditional methods as well as their advanced (such as cell wall composition analysis, whole-cell protein fingerprinting and fatty acid analysis) and automated (miniaturised kits or devices) applications often lead to uncertain identification or even misidentification, especially in cases of phenotypically closely related 
species. Failure to detect pathogens can have adverse health effects as well as substantial economic losses and fatalities. New approaches based on the application of molecular methods have being developed in the last years, bringing new insights in the detection of pathogenic bacteria in milk and milk-based products. In this chapter, we will endeavour to touch upon several nucleic acid based methods (such as PCR and its derivatives, real time PCR, REAPFGE, fAFLP, etc.) and their application in milk and dairy products.

\section{Nucleic acid-based detection and identification of milk- and dairy- borne pathogens}

Detection and identification methods to detect milk- and dairy- pathogens may be traced back to at least two basic techniques: direct hybridization and in vitro amplification. In the following paragraphs, due to their importance in the microbial safety of milk and its derivatives, and since most of the advanced molecular methods derive from these fundamental techniques, we will provide the basics of nucleic acid hybridization and polymerase chain reaction (PCR) as well as an excursus of the most used nucleic acid-based techniques to identify, quantitatively detect and type pathogenic microorganisms occurring in milk and dairy products.

\subsection{Nucleic acid hybridization}

\subsubsection{Basics}

DNA hybridization is mainly based on an intrinsic feature of the DNA molecule, such as the high specificity of base pairing (Figure 1) between homologous strands of single-stranded DNA. The deoxyribonucleic acid (DNA) structure consists in a double helix conformation of two polynucleotide strands held together by hydrogen bonds. DNA is composed of four repeating nucleotides: Adenine, Thymine, Cytosine, and Guanine (Figure 1). Each base is linked to a deoxyribose molecule, which is attached to a phosphate moiety. The various nucleotides are linked together via the $5^{\prime}$ carbon of the deoxyribose molecule and the phosphate group attached to the $3^{\prime}$ carbon (Figure 1). Each nucleotide base in the DNA strand will cross-link (via hydrogen bonds) with a nucleotide base in a second strand of DNA forming a structure that resembles a ladder (Figure 1). These bases cross-link in a very specific order: Adenine will only link with Thymine (and vice-versa), and Cytosine will only link with Guanine (and vice-versa) (Figure 1). Two single strands of DNA will bond together only if their base-pairs match up properly or complement one another [4].

The double stranded DNA may be broken by heat or high $\mathrm{pH}$. The reannealing between single stranded DNAs from different sources is called hybridization (Figure 2).

Standard nucleic acid hybridization assays require the use of a labelled nucleic acid probe (a denaturated DNA fragment varying in size from ten basepairs to kilobasepairs) to identify the target homologous DNA or RNA molecules within a complex mixture of unlabeled nucleic acid molecules, with the stability of the hybrid depending on the extent of base pairing that occurs [5]. Experimentally, the probe is usually labelled and the denatured 
target nucleic acid (DNA or RNA) is immobilized on a membrane or a polymer support or, if size information of the hybridization target is required, the target DNA is first run through agarose gel electrophoresis and then transferred to a membrane. The labelled probe is then added in a solution allowing the hybridization. After a suitable incubation, the membrane is washed in order to remove any non-specifically bound probe, leaving only the probe base-paired with the target DNA. By controlling the stringency of the washing conditions, DNA sequences $100 \%$ complementary to the probe or with lower degrees of similarity (i.e. with some mismatching) might be detected. In particular, having a sequence complementary to that of the target DNA, the probe might bind specifically to the target (previously denatured) and form with it a duplex DNA hybrid, recognizable by the labelled probe. The intensity of the spot is proportional to the amount of hybridized probe and therefore is proportional to the amount of target DNA in the sample. The intensity of the spot can be compared visually with the intensity of spots that correspond to a standard curve yielding semi-quantitative results (i.e., visual quantification), or the intensity can be determined using an instrument (e.g., densitometer) to create a quantitative value comparable with values obtained from the standard curve [6]. To overcome biohazards associated with the use of probes labelled with radioactive isotopes (usually $\mathrm{P}^{32}$ and $\mathrm{S}^{35}$ ), biotin, digoxigenin and different fluorochromes have been used for labelling $[7,8,9,10]$.

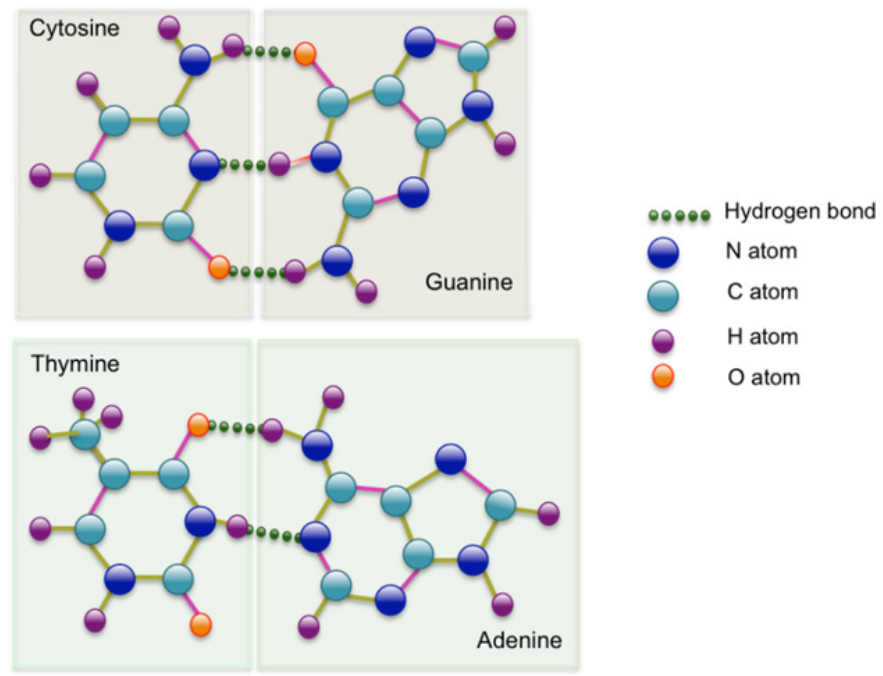

Figure 1. DNA base-pairing.

\subsubsection{Application}

Several technologies based on the nucleic acid hybridization, such as dot-blot [11], Southern[12] and Northern-blot [13], colony hybridization [14], colorimetric DNA hybridization [15] etc. have been developed and successfully applied to the pathogen detection [16-41] in milk and dairy products. 


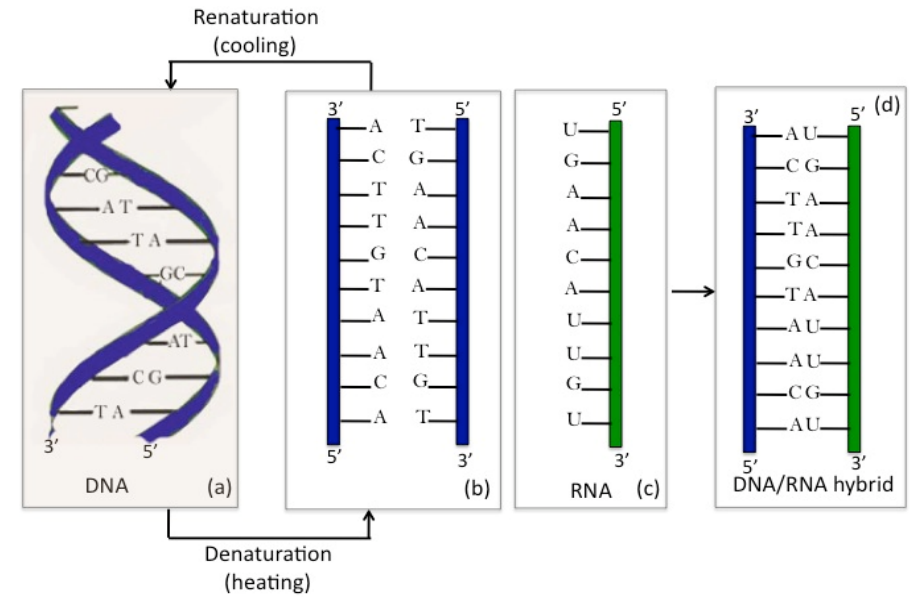

Figure 2. Nucleic acid hybridization.

However, a major drawback of the hybridization assays is their lack of sensitivity, which limits the use of these analyses to populations of cells or genes occurring in relatively high numbers in samples. For this reason, hybridization assays are currently mainly used for culture confirmation rather than direct detection and identification.

Among all the hybridization assays to date available, a particular focus should be given to the fluorescence in situ hybridization (FISH). FISH uses fluorescently labeled ribosomal RNA (rRNA) targeted probes and fluorescent microscopy to detect intact bacteria directly in food and clinical specimens, such as blood and tissue, or after enrichment culture [42,43]. Since this technique can visualize the precise location of a particular nucleic acid in the cytoplasm, organelli or nuclei of biological materials, it allows detecting metabollically active microorganisms directly in the environment without cultivation also providing useful information on the spatial distribution of the target organism in the colonised matrix. Experimentally, the procedure consists in preparing the samples, fixing it, preparing a smear or section on a microscope slide, permeabilizing the cells, hybridizing the probe to the DNA or RNA target in the sample and detecting the hybridization event by fluorescence microscopy. FISH assays have been developed and used to detect at family, genus and species level Staphylococcus spp., Listeria spp., Campylobacter spp., Salmonella spp. and E. coli $[44,45,46,47,48]$.

As the other hybridization assays, FISH suffers from sensitivity. Moreover, FISH may be hindered by microorganism and substrate inherent autofluorescence, insufficient permeability of cell walls, non-specific binding of probes and low ribosome contents.

\subsection{Polymerase chain reaction}

\subsubsection{Basics}

The polymerase chain reaction (PCR) succeeded in revolutionizing the analysis of nucleic acids, so much that a Nobel Prize was conferred to Kary Mullis [49]. It is an in vitro three- 
step amplification process first introduced by Saiki and co-workers [50]. In PCR reaction (Figure 3), mixtures of oligonucleotides (primers), properly designed to be complementary to the flanking regions of the target sequence to be amplified, are mixed in molar excess with the DNA template, free deoxyribonucleotides and a DNA polymerase enzyme in an appropriate buffer. Following heating to denature the original strands and cooling to promote primer annealing, the oligonucleotide primers bind to their complementary sequences in the target DNA. Then, the temperature is raised to the optimal temperature of a DNA polymerase, which begins polymerization, adding nucleotides to the 3 ' end of each primer attached to a single DNA strand. After one complete cycle, there are two double stranded copies of the target DNA. This process of denaturation, annealing, and polymerase extension repeated cyclically, produces many copies. Theoretically, 30 cycles over a billion copies of the target sequence $\left(2^{30}=1.07\right.$ billion $)$ could be provided.

The availability of both thermostable DNA polymerases, which resist to inactivation at the high temperatures used during the thermal cycling, and thermal cyclers, which could shift their temperatures up and down rapidly, automatically and in a programmed manner, have allowed the PCR to be automated. Amplicons, i.e. PCR products attended, can be visualized through several methods. Apart from DNA hybridization, one of the most used techniques to accomplish amplicon detection is the agarose gel electrophoresis using a buffer stained with a dye (ethidium bromide, SYBR Green etc.) that binds double stranded DNA and fluoresces upon excitation with UV light. By this way, it is possible to observe and photograph the gel by using an apparatus with a UV light source and an appropriate camera [51]. The presence of the target pathogen, regardless of its conditions (live or dead), can be ascertained by the presence in gel of the band relevant to the specific amplicon. Moreover, due to the inverse linear correlation recognised between the $\log _{10}$ size of the DNA fragment (basepair) and the distance migrated by the DNA fragment in the agarose gel during electrophoresis, it is possible to estimate the size of the amplicon from DNA standards loaded in the agarose gel. Other ways to accomplish the detection of PCR products include DNA hybridization and non-gel methods such as the enzyme-linked immunosorbent assay (ELISA) [52].

\subsubsection{Application}

PCR, together with culture and counting methods is been indicated as the most popular method used in pathogen detection [53]. Sequencing analysis of rRNA genes intergenic spacer regions as well as other phylogenetically important genes such as rpoB, hsp60 etc. and species-specific PCR of DNA fragments that are unique for a given microbial species, have been used to identify, detect and characterize pathogenic microorganisms. In Table 1, a list of PCR based methods developed and used to detect in milk and dairy products the five most concerned pathogens (Campylobacter spp., Salmonella spp., E. coli O157:H7, L. monocytogenes and S. aureus) is reported.

Among the different PCR variants to date available, multiplex PCR is very useful as it allows the simultaneous detection of several organisms by introducing different primers to amplify DNA regions coding for specific genes of each bacterial strain targeted. Apart from $16 \mathrm{~S}$ and 
$23 \mathrm{~S}$ rRNA and intergenic spacer regions, several genes have been targeted to allow multiplex milk- and dairy-borne pathogens identification, detection and characterization [54-66].

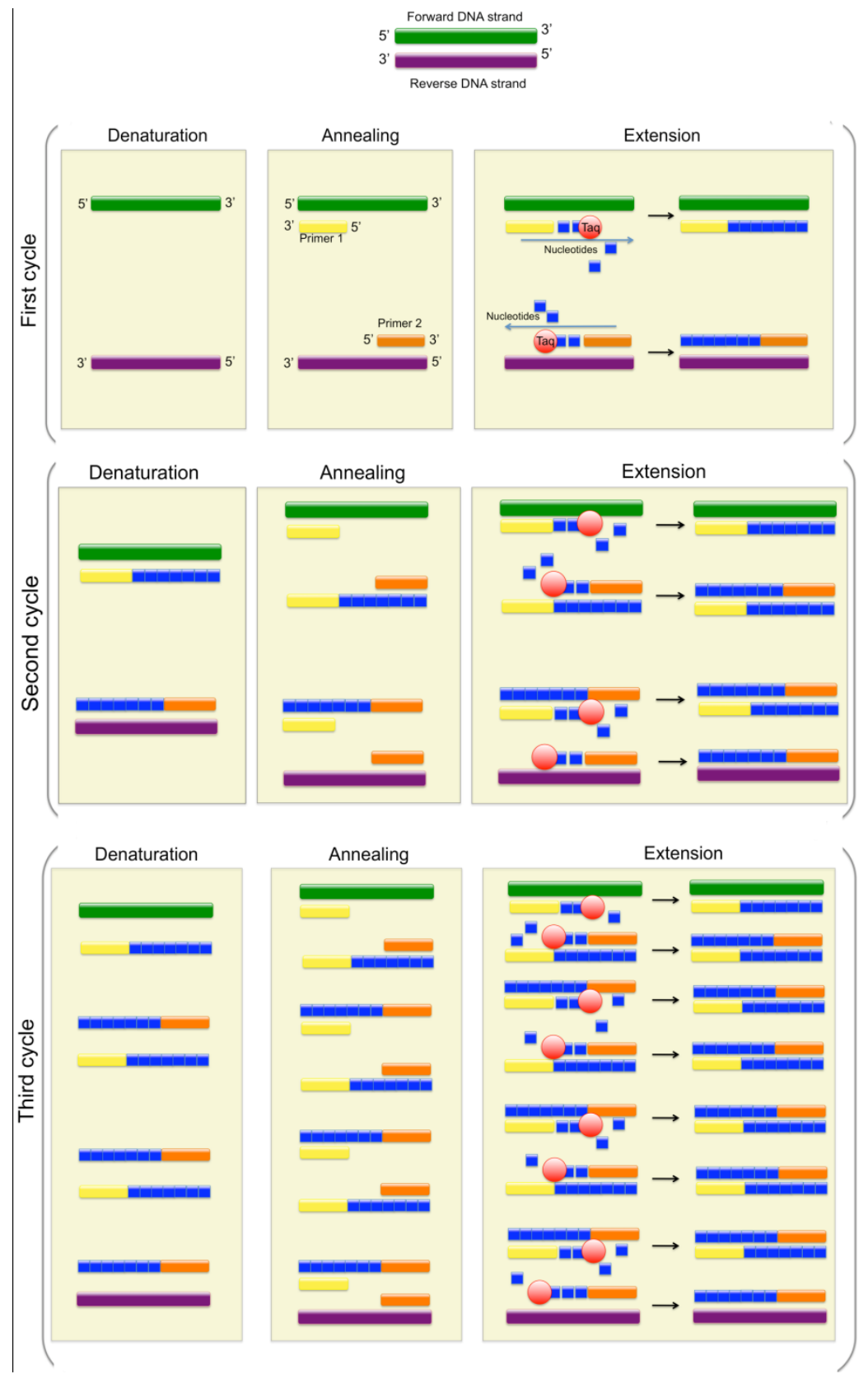

Figure 3. Polymerase chain reaction. 
Several targets have been used and several researchers have used the same target to develop different primer pairs to detect the same bacterial species. However, individual assessments of the specificity and sensitivity of a given assay may differ markedly and care should be taken in designing a PCR $[67,68]$. Moreover, taxonomy of several pathogenic bacteria is being continuously changed in the recent years, thus calling for a periodic re-validation of PCR assays. As an example, the taxonomy of Campylobacter has evolved every year since 1988 and to date it contains over 100 taxa. Within the EC 6th Framework "MoniQA" Network of Excellence project on harmonisation and standardisation of detection methods for foodborne hazards, we have recently participated, with other 7 laboratories of other 7 countries, in a revalidation study of 31 PCR assays for the identification of Campylobacter species, with particular reference to taxa described since 2004, which are closely related to the most concerned pathogenic species C. jejuni and C. coli [69]. It resulted that i) the sensitivity and specificity of these PCR assays varied considerably, ii) PCR assays recently developed to identify and detect a novel Campylobacter species (namely C. lari) were no successful in detecting all strains of this species, probably reflecting its complex taxonomy; and iii) several PCR assays gave false positive results for Campylobacter species described since PCR tests were reported (including C. cuniculorum, C. subantarticus, C. peloridis and C. volucris), thus highligthing the need for attention to detail in the design and evaluation of a PCR assay and also for ongoing revalidation of previously already validated PCR assays [69].

\begin{tabular}{|c|c|c|c|c|}
\hline \multirow{2}{*}{ Species } & \multirow{2}{*}{$\begin{array}{l}\text { Target gene or } \\
\text { fragment }\end{array}$} & \multirow{2}{*}{ Encoded product } & \multicolumn{2}{|c|}{ Reference } \\
\hline & & & $\mathrm{a}$ & $\mathrm{b}$ \\
\hline \multirow{2}{*}{$\begin{array}{l}\text { Listeria } \\
\text { monocytogenes }\end{array}$} & $16 S$ & $16 \mathrm{~S}$ rRNA & [70] & \\
\hline & hlyA & Listeriolysin & {$[71,72]$} & {$[73,74]$} \\
\hline \multirow{2}{*}{$\begin{array}{l}\text { Campylobacter } \\
\text { spp. }\end{array}$} & act $\mathrm{A}$ & Actin assembly-inducing protein & [75] & \\
\hline & $16 \mathrm{~S}$ & $16 \mathrm{~S}$ rRNA & [76] & \\
\hline \multirow{5}{*}{$\begin{array}{c}\text { Escherichia coli } \\
\text { O157:H7 }\end{array}$} & eae & Intimin & {$[77]$} & \\
\hline & stx1 (or VT1) & Shiga-like toxin 1 & & [78] \\
\hline & stx2 (or VT2) & Shiga-like toxin 2 & & {$[74,79,80]$} \\
\hline & hlyA & Haemolysin & & [62] \\
\hline & $r f b \mathrm{E}$ & $\begin{array}{l}\text { Lipopolysaccharide } \mathrm{O} \text { side chain of } \\
\text { E. coli } \mathrm{O} 157\end{array}$ & & {$[79]$} \\
\hline \multirow{2}{*}{ Salmonella spp. } & inv $\mathrm{A}$ & Invasion protein & & {$[81,82]$} \\
\hline & $\operatorname{stn}$ & Enterotoxin determinant & & {$[74]$} \\
\hline \multirow{5}{*}{$\begin{array}{l}\text { Staphylococcus } \\
\text { aureus }\end{array}$} & $n u c$ & Thermostable nuclease of S. aureus & [83] & {$[74,84-88]$} \\
\hline & sea & Staphylococcal enterotoxin A & [89] & {$[84,90-96]$} \\
\hline & $s e b$ & Staphylococcal enterotoxin B & {$[89,97]$} & {$[84,90-96]$} \\
\hline & $\mathrm{sec}$ & Staphylococcal enterotoxin C & [89] & {$[84,90-96,98]$} \\
\hline & $\sec 1$ & Staphylococcal enterotoxin C1 & [97] & [99] \\
\hline
\end{tabular}




\begin{tabular}{|c|c|c|c|c|}
\hline \multirow{23}{*}{ Species } & \multirow{2}{*}{$\begin{array}{l}\text { Target gene or } \\
\text { fragment }\end{array}$} & \multirow{2}{*}{ Encoded product } & \multicolumn{2}{|c|}{ Reference } \\
\hline & & & a & $b$ \\
\hline & sed & Staphylococcal enterotoxin D & [89] & {$[84,90-96]$} \\
\hline & see & Staphylococcal enterotoxin E & [89] & {$[84,90-96]$} \\
\hline & $\operatorname{seg}$ & Staphylococcal enterotoxin G & [89] & $\begin{array}{l}{[84,91-93,} \\
96,100,101]\end{array}$ \\
\hline & seh & Staphylococcal enterotoxin $\mathrm{H}$ & [89] & {$[91,92,94,96]$} \\
\hline & sei & Staphylococcal enterotoxin I & [89] & $\begin{array}{l}{[91,92,94,96,1} \\
00,101]\end{array}$ \\
\hline & selj & Staphylococcal enterotoxin-like J & [89] & {$[84,91,94,96]$} \\
\hline & selk & Staphylococcal enterotoxin-like K & & [94] \\
\hline & sell & Staphylococcal enterotoxin-like L & [89] & {$[91,94]$} \\
\hline & selm & Staphylococcal enterotoxin-like M & {$[84,102]$} & {$[94,100,101]$} \\
\hline & seln & Staphylococcal enterotoxin-like $\mathrm{N}$ & {$[84,102]$} & {$[94,100,101]$} \\
\hline & selo & Staphylococcal enterotoxin-like O & {$[84,102]$} & {$[94,100,101]$} \\
\hline & ser & Staphylococcal enterotoxin $\mathrm{R}$ & & [92] \\
\hline & ses & Staphylococcal enterotoxin S & & [92] \\
\hline & set & Staphylococcal enterotoxin $\mathrm{T}$ & & [92] \\
\hline & selu & Staphylococcal enterotoxin-like U & & [101] \\
\hline & selv & Staphylococcal enterotoxin-like A & & [101] \\
\hline & pent1 & Pseudogene $\phi e n t 1$ & & {$[100,101]$} \\
\hline & pent2 & Pseudogene $\phi e n t 2$ & & {$[100,101]$} \\
\hline & tsst & Toxic-shock syndrome toxin & & {$[84,92]$} \\
\hline & $e g c$ & Enterotoxin gene cluster & & {$\left[\begin{array}{l}{[84,92,100,101} \\
]\end{array}\right.$} \\
\hline & spa & Staphylococcus aureus protein A & & [103-106] \\
\hline
\end{tabular}

Table 1. List of target genes used in conventional PCR protocols for the identification, detection and characterization of some of the most concerned foodborne pathogens. Assays either specifically developed or employing already existing protocols for milk- and dairy- borne pathogens are listed in columns "a" and " $b$ ", respectively.

\subsection{Real time PCR}

Conventional PCR-based detection requires post-amplification confirmative analyses, which, apart from the potential DNA carry-over, are time- and labour-consuming. In real time PCR, fluorescent dyes are used to directly monitor the amplification of the target DNA. Moreover, because fluorescence increases in direct proportion to the amount of specific amplicons, real time PCR can be used for quantification. 
SYBR Green is one of the most frequently double-stranded (ds) DNA-specific dyes used in real-time PCR today. It is an asymmetric cyanine dye that can be excited with blue light with a wavelength of $480 \mathrm{~nm}$ and having an emission spectrum comparable to that of fluorescein with a maximum at $520 \mathrm{~nm}$ [108]. Being a DNA binding dye, SYBR Green allows the detection of any double-stranded DNA during the PCR. Strength and, at the same time, weakness of this system is that, being nonspecific, it can also bind any spurious product (dimers, artefacts etc.). To overcome this problem a melting curve analysis may be carried out at the end of the real time PCR amplification. The strand-specific methods have a higher specificity since they employ fluorophore-coupled nucleic acids to interact with reaction products, probing accumulating PCR products for the presence of the target sequence.

The most commonly used fluorogenic oligoprobes rely upon the fluorescence resonance energy transfer (FRET) between either fluorogenic labels or a fluorophore and a dark or blackhole non fluorescent quencher (NFQ), which disperses energy as heat rather than fluorescence [107]. The FRET spectroscopic process consists in an energy transfer between molecules separated by 10-100 Angstroms, which have overlapping emission and absorption spectra [107].The theory behind this non-radioactive induced dipole interaction process was developed by Förster [109]. The efficiency of this process mainly depends on the distance between fluorophores. Indeed, the sequence-specific signals are generated due to the PCR-product-dependent change in distance between fluorophores [108].

TaqMan probes contain two dyes, a reporter dye (e.g. 6- carboxy-fluorescein; FAM) at the $5^{\prime}$ end and a quencher dye (e.g. 6-carboxy-tetrametyl-rhodamine; TAMRA) at the $3^{\prime}$ end. The proximity of the quencher dye to the reporter in an intact probe allows the quencher to suppress, or "quench", the fluorescence signal of the reporter dye through FRET. If the target of interest is present, these probes specifically anneal between the forward and reverse primer sites. During the real time PCR amplification, the $5^{\prime}$ to $3^{\prime}$ nucleolytic activity of the Taq DNA polymerase cleaves the probe between the reporter and the quencher, only if the probe hybridizes to the target. Thereafter, the quencher is released from the fluorophor, which now fluoresces after excitation.

The signal increases in direct proportion to the amount of PCR product in a reaction [107]. Accumulation of PCR products is detected directly by monitoring the increase in fluorescence of the reporter dye. The average background fluorescence is usually measured for the first 10 cycles of the reaction and subtracted from each fluorescent reading, resulting in a standardized amplification plot of fluorescence intensity against cycle number for each reaction. The cycle threshold $(\mathrm{Ct})$, defined as the first cycle in which there is a significant increase in fluorescence above a specified threshold, is then calculated and the fluorescence against the cycle number is plotted to obtain a curve that represents the accumulation of PCR products in function of time. Running several reactions containing dilutions of known amount of target DNA a standard curve can be created and used to quantify unknown amounts of target DNA [107].

Being time-saving (especially the "fast systems" and requiring reduced handling, avoiding the risk of carryover contaminations, real time PCR is revolutioning the clinical, food and 
environmental diagnostics. Moreover, depending on the detection platform utilised, it is very highthroughput being possible to process either 96 or 384 samples per run even in a multiplexing format. Simplex and multiplex real time PCR assays have been developed and used to identify and quantitatively detect directly and undirectly in milk and dairy products, S. aureus, L. monocytogenes, Salmonella spp., E. coli O157:H7 and Campylobacter spp. (Table 2). When the culture-independent approach is performed the availability of an appropriate DNA extraction and purification protocol is crucial. Milk and its derivatives, due to their intrinsic complexity (in terms of composition and structure) and the likely presence (in raw milk based products) of abundant background microflora, may significantly affect the efficiency of both the nucleic acid extraction and PCR amplification $[66,86,110-113]$. Moreover, in such cases, it is of outmost importance to use standard curves appropriate to the specific case to be analysed. Fusco et al. [101] developed a TaqMan and a SYBR Green rt-PCR based assay targeting the enterotoxin gene cluster of $S$. aureus, regardless of its variants, for the rapid and reliable identification and quantitative detection of egc $\mathrm{c}^{+}$S. aureus strains (i.e. S. aureus harbouring the enterotoxin gene cluster). In addition, given the well recognised role of $S$. aureus as one of the commonest aetiological agent of clinical and sub-clinical mastitis [114-116] and considering that milk and milk-based products contaminated with this pathogen are some of the food matrices more often involved in staphylococcal food poisoning [117-122], they evaluated the effectiveness of these novel assays in artificially and naturally contaminated raw milk [101]. To achieve these goals, standard curves were constructed using ten-fold dilutions of target pre-purified DNA, or DNA extracted from ten-fold dilutions of a egc $c^{+}$. aureus strain in broth and in raw milk [101]. Moreover, in order to determine the diagnostic sensitivity, defined as a measure of the degree to detect the target pathogen in the biological matrix, and to assess the applicability of the assay in simulated staphylococcal food poisoning conditions (i.e enterotoxin positive $S$. aureus concentration above $10^{5} \mathrm{cfu} \mathrm{mL}^{-1}$ ), three standard curves in raw milk were constructed using log phase broth cultures of either a single egc ${ }^{+} S$. aureus strain, a mix of $e g c^{+} S$. aureus strains and a mix of egc and egc- $S$. aureus strains harbouring (and not) some of the commonest enterotoxin genes associated to this syndrome [101]. Overall, the TaqMan assay revealed less sensitivity (limit of quantification $=10^{2}$ cfu equivalents per reaction mixture of $e g c^{+} S$. aureus either singly, in mix and in mix with egc $S$. aureus strains) in milk than in DNA (pre-purified and not), thus highlighting the importance of using a standard curve in raw milk to accurately quantify egc $S$. aureus in real raw milk samples [101].

\begin{tabular}{|c|c|l|c|c|}
\hline \multirow{3}{*}{ Species } & Target gene & & \multicolumn{2}{|c|}{ Reference } \\
\cline { 3 - 5 } & hlyA & Listeriolysin & $\mathrm{a}$ & $\mathrm{b}$ \\
\hline \multirow{3}{*}{$\begin{array}{c}\text { Listeria } \\
\text { monocytogenes }\end{array}$} & ssrA & tmRNA & {$[123,124]$} & {$[125]$} \\
\cline { 2 - 5 } & prfA & $\begin{array}{l}\text { Transcriptional regulator PrfA; listeriolysin } \\
\text { positive regulatory protein }\end{array}$ & {$[126]$} & {$[127]$} \\
\cline { 2 - 5 } & $16 S$ & 16S rRNA & {$[130]$} & \\
\cline { 2 - 5 } & & & \\
\hline
\end{tabular}




\begin{tabular}{|c|c|c|c|c|}
\hline \multirow{3}{*}{ Species } & \multirow{2}{*}{ Target gene } & \multirow{2}{*}{ Protein } & \multicolumn{2}{|c|}{ Reference } \\
\hline & & & a & $\mathrm{b}$ \\
\hline & 16S-23S rRNA IGS & $\begin{array}{l}\text { Intergenic region spacer between the } 16 \mathrm{~S} \\
\text { and } 23 \mathrm{~S} \text { rRNA }\end{array}$ & {$[131]$} & {$[132]$} \\
\hline \multirow{3}{*}{$\begin{array}{c}\text { Staphylococcus } \\
\text { aureus }\end{array}$} & $e g c$ & Enterotoxin gene cluster & {$[101]$} & \\
\hline & $h t r \mathrm{~A}$ & $\begin{array}{l}\text { High-temperature-requirement } \\
\text { A protein }\end{array}$ & {$[133]$} & \\
\hline & $n u c$ & Thermostable nuclease & {$[134]$} & \\
\hline \multirow{4}{*}{ Escherichia coli } & $s t x 1$ & Shiga-like toxin 1 & {$[135]$} & \\
\hline & $s t x 2$ & Shiga-like toxin 2 & {$[135,136]$} & \\
\hline & eae & Intimin & {$[135]$} & {$[30]$} \\
\hline & stx1, stx 2 & Shiga-like toxin 1 e 2 & {$[137]$} & [30] \\
\hline $\begin{array}{l}\text { Campylobacter } \\
\text { spp. }\end{array}$ & VS1 & C. jejuni specific fragment & {$[138]$} & \\
\hline \multirow[t]{2}{*}{ Salmonella spp. } & ttrRSBCA & $\begin{array}{l}\text { Proteins involved in tetrathionate } \\
\text { respiration }\end{array}$ & [139] & \\
\hline & $\operatorname{inv} \mathrm{A}$ & Invasion protein & {$[140]$} & \\
\hline
\end{tabular}

Table 2. List of target genes used in simplex and multiplex real-time PCR protocols for the identification, (quantitative) detection and characterization of some of the most concerned foodborne pathogens. Assays either specifically developed or employing already existing protocols for milk- and dairy- borne pathogens are listed in columns " $a$ " and " $b$ ", respectively.

\subsection{Detecting stressed or injured pathogens: EMA and PMA PCR/real time PCR, reverse transcription PCR/real time PCR and NASBA}

The complexity and variability of food composition as well as physical and/or chemical stresses that pathogenic microorganisms encounter in the environment, in foods and food preparation/production/storage processes, if inadequate or sub lethal, may result in incomplete inactivation [141,142]. Such injured or stressed bacteria are a potential risk since they can, under appropriate conditions, recover and regain or even enhance their pathogenicity [141,143-145]. Failure to detect injured pathogens can have adverse health effects as well as fatalities and economic losses. All these findings prompt the need for improved enumeration methods capable of discriminating among viable, dead, and injured microbial cells. Conventional culture based methods do not allow the enumeration of stressed or injured bacteria, as they use selective agents whose injured or stressed pathogens' cells, depending on the site and degree of damaging, are extremely sensitive [142]. The inadequateness of highly selective solid and liquid media remarkably complicates the detection of pathogenic bacteria in foods characterized by a complex and numerous background microflora, such as milk and milk-based products. The major drawback in using DNA-based assays to detect pathogenic microorganisms is that DNA is detectable in both viable, injured and dead cells of a given microorganism also after a long period of time $[86,146]$. However, DNA amplification techniques may be combined with the use of 
molecules able to penetrate in dead or injured cells and bind to DNA making it insoluble so that it can be easily eliminated together with cell debris during genomic DNA extraction. Ethidium monoazide- (EMA) and propidium monoazide (PMA) conventional and real time PCRs have been applied to the detection and quantification of different food-borne pathogens [147-150]. PMA seems to have the important advantage over EMA of not penetrating living cells [149].

Stressed or injured pathogens cells may be quantitatively detected by PCR methods combined with a solid or a liquid based enumeration method in which stages of "revivification" have been introduced to restore and therefore bringing back in conditions of perfect viability and cultivability the greater number of stressed cells, not directly cultivable $[79,123]$.

To address the need of detecting only living pathogens RNA may be detected rather than DNA [151-155].

Reverse Transcription (RT) PCR makes use of a reverse transcriptase, which, in presence of a complementary primer, can translate an RNA strand corresponding to a transcribed gene into complementary DNA (cDNA). The reaction is usually initiated by random oligonucleotide primers. Thereafter, the cDNA is used as template to amplify by PCR specific sequences using oligonucleotide primers and DNA polymerase under normal PCR or real time PCR conditions.

Another way to target mRNA as an indicator of cell viability is to employ the nucleic acid sequence-based amplification (NASBA). It is an isothermal nucleic acid amplification technology allowing the amplification of RNA or DNA targets (with a slight modification in the protocol) through a transcription process after the insertion of a T7 promoter, due to the concerted action of three enzymes: AMV Reverse Transcriptase for cDNA synthesis, RNase $\mathrm{H}$ to degrade the RNA in the heteroduplex RNA-DNA and T7 RNA polymerase to synthesize RNA from the T7 promotor [156].

Both the NASBA and the reverse transcription conventional and real time PCR techniques have been used for developing diagnostic tests to detect viable pathogenic microorganisms [157-159]. Since NASBA is performed in isothermal conditions, it does not require the use of a thermocycler. Therefore, it is less expensive than PCR and RT-real time PCR.

\subsection{Biosensors, microarrays, micro and nano electro-mechanical-systems}

Biosensors have been recognized as a means to provide a higher level of surveillance in a more automated and rapid manner. These analytical devices combine a biological sensing element (called receptor) with a chemical or physical transducer for selectively and quantitatively detecting a given compound. In complex matrices only the compound interacting specifically with the integrated biological component will generate the optical or electrical signal from the physical transducer, modulating the biosensors' selectivity [53]. Such specific interactions produce a physico-chemical change, detected and measured by the transducer that can output a signal proportional to the concentration of the target analyte, allowing for both real time 
quantitative and qualitative measurements. The chemico-physical change detected by the transducer may be: 1) absorption or evolution of heat (thermometric or calorimetric biosensors), 2) changes in the distribution of charges causing an electrical potential to be produced (potentiometric biosensors), 3) movement of electrons produced in a redox reaction (amperometric biosensors), 4) light radiation or difference in optical properties between the reactants and products (optical biosensors) and, 5) effects due to the mass or intermolecular interaction of the reactants or products (piezo-electric biosensors) [53,160]. Enzymes, antibodies, DNA, receptors organelles and microorganisms as well as plant cells or tissues are frequently used as biological sensing elements [161].

Many biosensors for food diagnostic application in the food and drink industry are currently being developed [161-166]. Among these, biosensors that can detect DNA are of particular interest. Intrinsic features of the DNA molecule, such as the high specificity of base pairing between homologous strands of single-stranded DNA, as well as its predisposition to electrical, fluorescent and mechanical measurements, make it a highly specific sensing element, and render it useful for signal transduction in a wide range of DNA based biosensors $[167,168]$.

Hybridization biosensors rely on the immobilization of a species- or strain- specific single stranded DNA probe onto the transducer surface. Due to the characteristic negative charge of DNA, the duplex formation can be detected for example by following the association of an appropriate hybridization indicator. Hybridization events between analyte and probe DNA may be translated through electrochemical, optical, or mechanical output signals [169]. As for other types of biosensors, high selectivity is crucial for the success of DNA hybridization devices. The specificity of these sensors depends primarily on the selection of the probe, and secondarily upon the hybridization conditions (mainly the temperature).

Microarrays, based on the Watson-Crick base pairing principle [4], consist of genetic sensors, the so-called "spots," each containing single strands of species- or strain- specific DNA sequences termed probes immobilized at pre-determined position at high density. The DNA sequence of a target organism's genetic sample, previously labelled (through PCR amplification), will hybridize with its complementary sequence on the microarray to form a stable structure. After washing away non-specifically bound targets, the array is scanned using laser light of a wavelength designed to trigger fluorescence in the spots where binding has occurred. A specific pattern of array spots will fluoresce, which is then used to infer the genetic makeup in the test sample [170]. Microarray analysis is an emerging technology that has the potential to become a leading trend in bacterial identification in the dairy and overall in the in food and drink industry, allowing both the detection and/or genotyping of pathogenic microorganisms [171-179].

Due to the robust nature of PCR and the high sensitivity that can be achieved through amplification of target DNA, PCR-based biosensing has been widely used [168,180].

For PCR based-biosensing of bacteria optical methods of detection are widely used. In the case of the "real time PCR-based biosensor" the fluorescence emission is the measurable signal 
allowing the translation of the DNA amplification. DNA-based biosensor technologies are in constant evolution. In particular, there is a growing tendency toward miniaturization of these systems [167]. In recent years, micro- and nano- fabrication technologies, originally developed for producing silicon-based chips for the microelectronics industry, have spread out in a variety of applications as chemical and biochemical tools, commonly referred to as Biomedical or Biological Micro (and nano)-Electro-Mechanical Systems (BioMEMS or bioNEMS). BioMEMS and devices have been used as biosensor for the detection of bacteria, and the resulting biochips, also known as lab-on-a-chip devices, incorporate multiple laboratory processes in a semi-automated, miniaturized format, allowing rapid, sensitive and real-time measurements [163,164,180-183]. Obvious advantages of the miniaturized integrated detection technologies include higher sensitivity, as well as reduced reagent and sample volumes, reducing associated costs and time to result.

An example of such useful devices is given by the integrated microfluidic platform, known as the "microFLUIDICS DESKTOP" (Figure 4), developed by Cady and co-workers [185] for detecting Listeria monocytogenes by real time PCR. Monolithic DNA purification/real-time PCR silicon chips (Figure 5) were fabricated utilizing standard semiconductor processing technologies. These chips incorporated a microfabricated DNA purification chamber with a second PCR amplification chamber, connected by microfluidic channels.

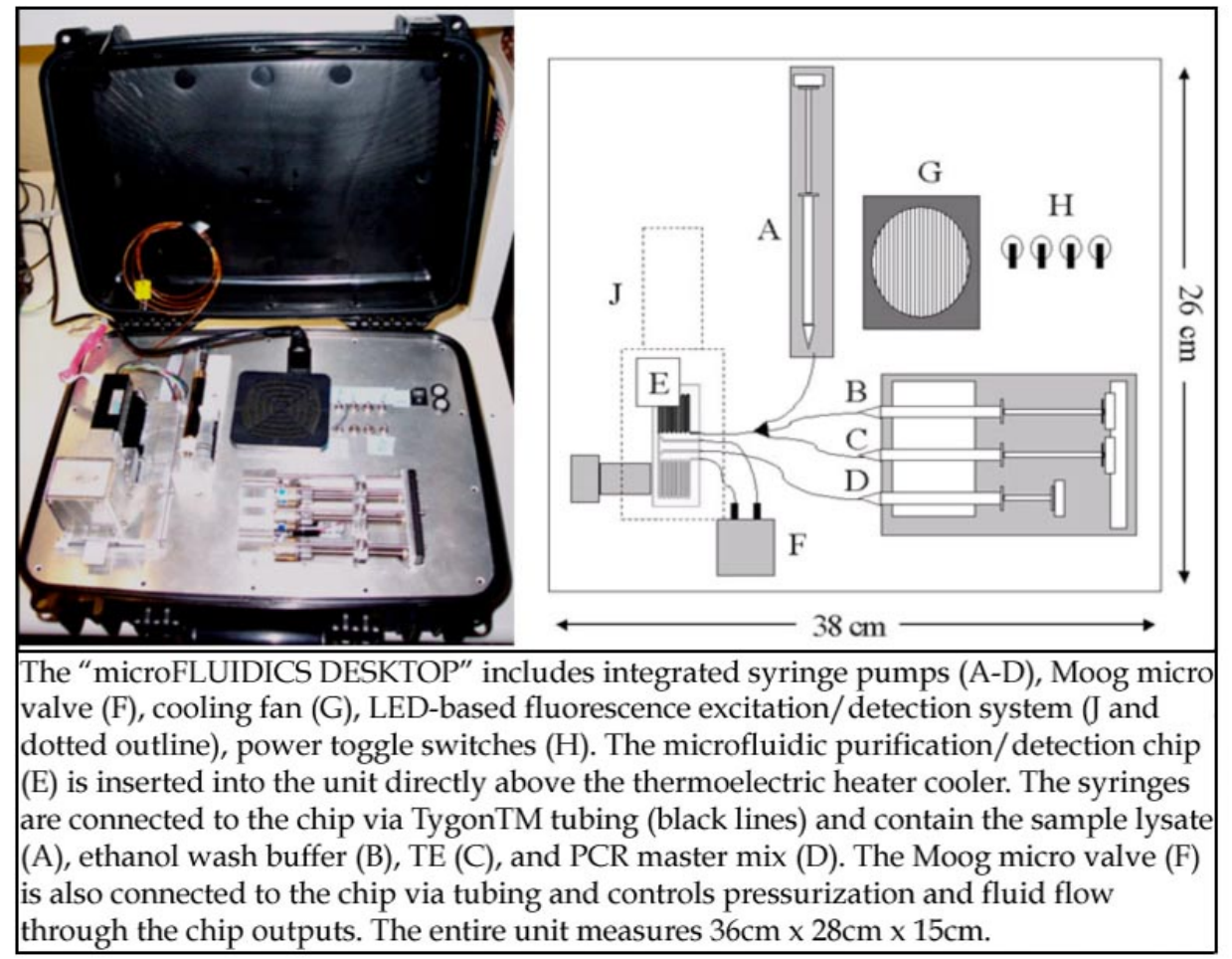

Figure 4. The "microFLUIDICS DESKTOP" [184,186]. 


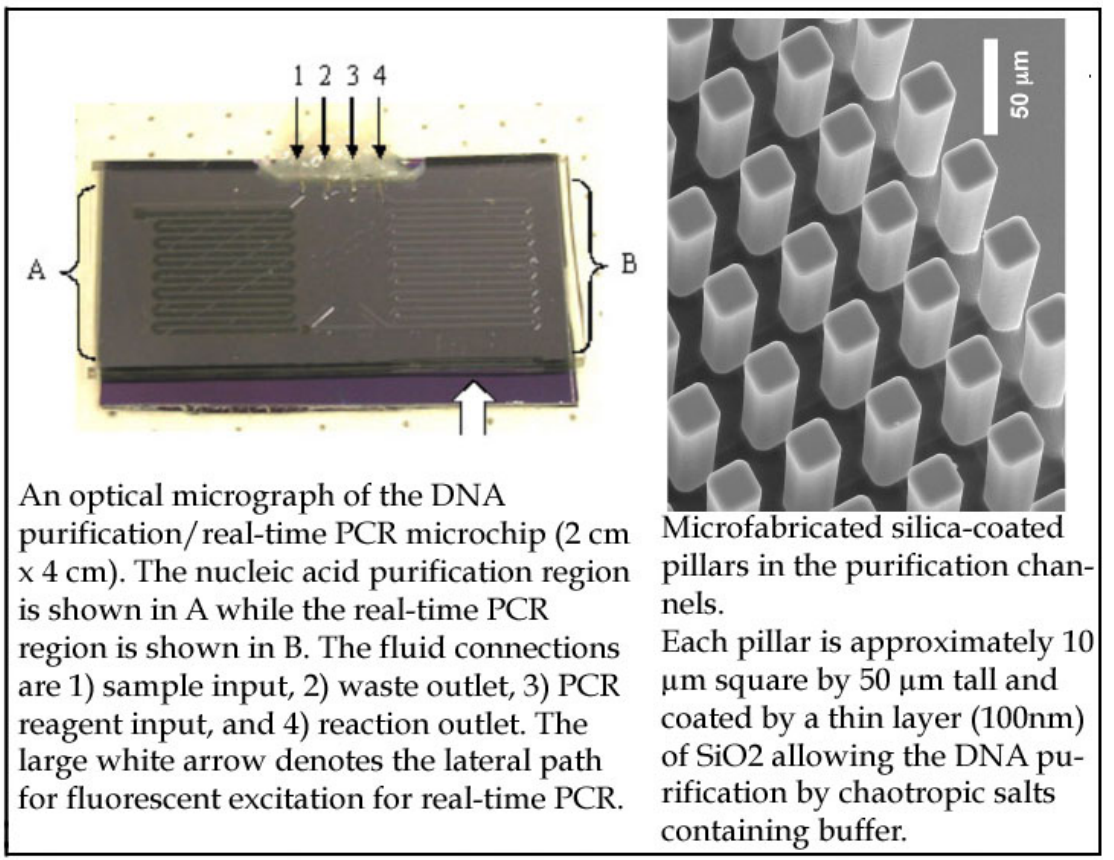

Figure 5. The monolithic DNA purification/real time PCR microchip [184-186].

The DNA purification section contained an array of $10 \mu \mathrm{m}$ square pillars that were etched 50 $\mu \mathrm{m}$ deep in silicon to form a microfluidic channel. These pillars were coated with a thin layer $(100 \mathrm{~nm})$ of $\mathrm{SiO} 2$ that could be used for DNA purification in chaotropic salt-containing buffers [185]. Using an automated detection platform with integrated microprocessor, pumps, valves, thermocycler and fluorescence detection modules, microchips were used to purify and detect bacterial DNA by real-time PCR amplification using SYBR Green fluorescent dye. This system was able to both purify and quantify DNA from $10^{7}$ to $10^{4}$ cells by SYBR Green real-time PCR-based detection, with an average turnaround time of $45 \mathrm{~min}$. The "microFLUIDICS DESKTOP" has been successfully used for the more specific TaqMan real-time PCR detection of $S$. aureus [186].

In an improvement over other systems, which are time consuming and require multiple laboratory instruments, this device provides a fully automated method capable of purifying DNA from bacterial cells and preparing samples for PCR-based detection.

Obvious benefits of such device include: reduced time to result; reduced amount of expensive reagents used; reduced handling, avoiding sample contaminations; the possibility to perform a multiplex assay for revealing various pathogenic microorganisms, by incorporating on-board multiple detectors; the possibility to further miniaturize a multifunctional integrated system, which can be developed as a truly portable device to be used for on-line and on-site rapid control of the whole food/beverage chain. 


\section{Typing}

In diagnostic microbiology, besides identifying a pathogenic microorganism, it is of outmost importance to type it. Typing, or subtyping (synonymous used in the American literature) has been defined as: "Phenotypic and/or genetic analysis of bacterial isolates, below the species/subspecies level, performed in order to generate strain/clone-specific fingerprints or datasets that can be used, for example, to detect or rule out cross-infections, elucidate bacterial transmission patterns and find reservoirs or sources of infection in humans" [187]. Several typing methods are to date available for discriminating microorganisms at strain level: the choice should be based on their appropriateness for each specific purpose. Whatever typing method is chosen, it has to be evaluated and validated in respect to several performance criteria (stability, typeability, discriminatory power, epidemiological concordance, reproducibility, test population) and convenience criteria (flexibility, rapidity, accessibility, easy of use, cost, amenability to computerised analysis and incorporation of typing results in electronic databases) prior to use it in a given study [187]. Conventional typing methods, based on the phenotypic features of microorganisms, including biotyping, serotyping, antibiogram-based typing (antimicrobial susceptibility testing), phage and bacteriocin typing, sodium dodecyl sulphate-polyacrilammide gel electrophoresis (SDSPAGE) of cellular and extracellular components, multilocus enzyme electrophoresis (MLEE), mass spectrometry (MS), matrix-assisted laser desorption/ionization-time of flight (MALDI-TOF) MS, Infrared or Raman spectroscopy, Fourier transform Infrared spectroscopy, etc. are being gradually overtaken by nucleic acid-based methods. The advent of the PCR technology and the development of bioinformatics tools have allowed implementing protocols to investigate the inter- and intra- specific heterogeneity of pathogenic microorganisms based on genotypic characters, which, unlike the phenotypic ones (on which rely conventional typing methods) are certainly the most reliable, being little or not influenced at all by exogenous factors. As for the detection and identification methods, nucleic acid based methods may be grouped into three main clusters including nucleic acid hybridization-, amplification- and fragment based typing methods and a third cluster including methodologies that combine all the above mentioned techniques. Herein, an excursus of the most important molecular methods used to type the five most concerned pathogenic bacteria will be reported.

Acronyms such as RAPD- (Random Amplified Polymorphic DNA), DAF- (DNA Amplification Fingerprinting) and AP-PCR (arbitrarily Primed PCR), define a set of methodologies having, as lowest common denominator, the possibility to amplify anonymous DNA sequences by using a single oligonucleotide as a primer for the Taq Polymerase [188,189]. Under conditions allowing the annealing of the primer at several points, a complex banding pattern should be obtained that could be characteristic for each strain. Methods such as REP- (Repetitive Extragenic Elements Palyndromic), ERIC(Enterobacterial repetitive Intergenic Consensus Sequence), BOX-, VNTRs- (Variable Number of Tandem Repeats) PCR, being based on the detection of repetitive regions of the genomic DNA, varying in length and number, have been individuated as more reliable and robust than RAPD-PCR to type pathogens [188,190-192]. 
Classical Restriction Fragment Length Polymorphism (RFLP) analysis combines the restriction endonuclease analysis with a Southern hybridization step. By this technique, genomic restriction fragments are separated by gel electrophoresis and then transferred to membranes, where they are hybridized with a labelled probe for specific DNA fragments that are present in the bacterial genome. Microbial strains are thereafter discriminated based on the size and number of restriction fragments that are homologous to the probe. A variation of RFLP, which is also one of the most used nucleic acid hybridization based method to type pathogenic bacteria, is ribotyping. This technique, originally used to establish phylogenetic relationships [193], is based on the restriction enzyme digestion of chromosomal DNA followed by Southern hybridization with a probe specific to conserved regions of the rRNA coding sequence. The resulting banding patterns are analysed to sort isolates into ribotypes also establishing the relatedness of isolates [193]. Using an automated ribotyping system, the RiboPrinter ${ }^{\circledR}$ (Qualicon Inc., Wilmington, Del., U.S.), this assay has been shortened from five days to eight hours. It has been demonstrated that the discriminatory power of this technique can considerably increase by using multiple ribopatterns to determine the overall ribotype of isolates [194]. Ribotyping has been widely used to characterise milk- and dairy- borne isolates of L. monocytogenes [195-200], S. aureus [201,202], E. coli O157:H7 [203,204], Salmonella spp. [205] and Campylobacter spp. [206,207]. rDNA based fingerprints can be obtained also by ARDRA (Amplified rDNA restriction analysis). In this case, bacterial rRNA gene(s) are amplified by PCR and digested with restriction endonuclease enzyme(s). The resulting restriction fragments are then resolved by gel or capillary electrophoresis to obtain a fingerprint [208]. However, although ARDRA is faster and easier to perform, it has a lower discriminatory power than ribotyping, because smaller areas of the rRNA operon are targeted. Other methods are available to obtain restriction maps providing strain-specific fingerprints of pathogenic bacteria. PCR-RFLP, based on the amplification of a given gene or operon, coupled with the digestion with appropriate endonuclease enzymes and electrophoresis of the resulting restriction fragments, has been used to characterise milk- and dairy- borne S. aureus [84,100,209], L. monocytogenes [2010-212], E. coli O157:H7 [213], Salmonella spp. [214,215] and Campylobacter spp. [216,217] isolates.

Restriction endonuclease analysis of genomic DNA fragments separated by pulsed-field gel electrophoresis (REA-PFGE) has become the "gold standard" for molecular typing $[187,218]$. By this technique, intact genomic DNA, obtained by performing the DNA extraction and purification of microbial cells imbibed in low melting agarose, is digested by rare-cutting endonuclease enzymes. The resulting restriction fragments, usually fewer than 30 ranging in size between 20 and 600 kilobasepairs, are then separated in agarose gels by the periodic alternation of the angle of the electric's field direction through PFGE, thus obtaining banding patterns that can be compared for each isolate to discriminate the different pulsotypes. Despite its lower convenience criteria, as it is more laborious, time consuming and expensive (it requires skilled labour, specialised equipment and expensive restriction endonucleases) than the other molecular typing techniques to date available, REA-PFGE has superior performance criteria (mainly discriminatory power and reproducibility) due to both the quality and quantity of banding patterns obtainable, which in turn are due to the intrinsic nature of the REA-PFGE. PulseNet (www.cdc.gov/pulsnet), which is a network of health and food regulatory laboratories created by the the Center for Disease Control and 
Prevention [1], uses PFGE for typing foodborne pathogens, allowing a better tracking and earlier detection of possible common source outbreaks [219,220]. As several similar initiatives have been developed in other countries (129 laboratories from 70 countries trained on PulseNet methods in Latin America, Canada, Europe, the Middle East, Asia Pacific) the PulseNet international (www.pulsenetinternational.org) has been developed. Networks like these rely upon standardization of REA-PFGE and regular quality assessment through appropriate ring trials for all participating laboratories, in order to warrant consistently comparable data.

Informative polymorphic banding patterns can be obtained by amplified fragment length polymorphism (AFLP) allowing the differentiation with a high discriminatory power (as it involves, like REA-PFGE, the whole genome) even of phylogenetically closely related bacteria without any prior information on their genomes [110, 221]. This multi-locus fingerprinting technique combines the reliability of RFLP analysis with the flexibility and robustness of PCR using restriction site/adaptor-specific primers under stringent conditions $[110,222]$. Semi-automated versions of this technique may be obtained by the fluorescent AFLP (fAFLP) using capillary array systems, fluorescently labelled primers and adequate analysis software [223], which provide digitised and complex DNA fingerprints, covering nearly the whole genome [110]. AFLP has been used to type Salmonella spp., E. coli O157, Campylobacter spp., S. aureus and L. monocytogenes [203,223-228].

Typing of pathogenic microorganisms can be achieved by PCR based methods. Conventional and, more proficiently, real time PCR, either in simplex or (better) in multiplex format of enterotoxins' and/or other virulence factors' encoding genes may provide valuable information on the potential pathogenicity of a given isolate (paragraph 2.2 and 2.3). The same achievement can be reached by using the microarray technology (described above).

PCR amplification and sequencing analysis of (usually) seven house-keeping genes is the basics of the Multilocus Sequence Typing (MLST), which, being based on sequence data, is an unambiguous procedure to characterize isolates of bacterial species $[229,230]$. If virulence and virulence-associated genes are used this technique is referred to as Multi-Virulence Locus Sequence Typing (MVLST) [231]. Since MLST relies upon specific nucleotide base changes to type microorganisms, it is easiest to perform (it can be automated by using an automated pipetting platform and an automated sequencer) and analyse unlike other typing procedures which compare complex fingerprints rather than sequence data and allelic profiles. Of course, high quality sequences results are essential in this method. Being a highly reproducible and reliable technique, by which results, i.e. strings of digits representing different alleles, are easily and unequivocally exchangeable, as for REA-PFGE, a multilocus sequence network has been developed (www.mlst.net).

\section{Conclusion}

As it emerges from the reading of the present chapter, a plethora of nucleic acid based methods are to date available for the detection, identification and typing of milk- and dairy- 
borne pathogenic microorganisms. However, none of these is perfect, harbouring wikenesses besides strenghts such as suboptimal reproducibility, sensitivity or discriminatory power. It can be inferred that the choice of the most appropriate method should rely upon the specific needs and, of course, on the available equipment for carrying out the task. Nucleic acid-based methods are gradually replacing traditional methods to identify, detect and type pathogenic microorganisms in milk and dairy products. Several efforts are being made to overcome limitations of these methods, mainly related to their sensitivity and accuracy besides the effectiveness in respect to the complex target food matrices, and achieve the validation and standardization of these approaches, which are basic requirements to become reference methods. As concerns identification and detection systems, the major perspective in the nearest future is the possibility to use portable miniaturized integrated devices allowing the rapid and reliable detection and quantification of pathogenic microorganisms directly from food. Such detection platform will decrease the risk of contaminating the food/feed/beverage supply, preventing a wide dissemination of contaminated foods and the possibility of a disease outbreak, as well as facilitate real-time preventive measures along the whole food/feed/beverage chains. On the other side, next generation sequencing and other user-friendly nucleic acid-based automated platform will provide promising way of achieving the genetic typing of milk- and dairy- borne pathogenic microorganisms.

\section{Author details}

Vincenzina Fusco and Grazia Marina Quero

National Research Council, Institute of Sciences of Food Production (CNR-ISPA), Bari, Italy

\section{Acknowledgement}

This review was prepared within the European Community's Seventh Framework Programme (FP7/ 2007- 2013) under the grant agreement no FP7-222 654-DREAM.

\section{References}

[1] Centre for Disease Control and Prevention (2011) CDC 2011 estimates of foodborne illness in the United States. Factsheet printable and downloadable from the following url: http://www.cdc.gov/foodborneburden/2011-foodborne-estimates.html

[2] European Food Safety Autority (EFSA), European Centre for Disease Control and Prevention (ECDC) (2011) Scientific report of EFSA and ECDC. The European Union summary report on trends and sources of zoonoses, zoonotic agents and food-borne outbreaks in 2009. EFSA Journal 2011 9:2090, 1-378.

[3] FDA (2007) Food Protection Plan. Department of health and human services. Maryland: US. Food and Drug Administration.

[4] Watson JD, Crick FHC (1953) Molecular structure of nucleic acids: a structure for deoxyribose nucleic acid. Nature 171:737-738. 
[5] Strachan T, Read AP (1999) Nucleic acid hybridization assays. In: Human molecular genetics, 2nd edition. D: Strachan T., Read, A.P. New York: Wiley-Liss.

[6] Olsen JE, Aabo S, Hill W, Notermans S, Wernars K, Granum PE, Popvic T, Rasmussen HN, Olsvik O (1995) Probes and polymerase chain reaction for detection of foodborne bacterial pathogens. Int. J. Food Microbiol. 28: 1-78.

[7] Fang X, Liu X, Schuster S, Tan W (1999) Designing a novel molecular beacon for surface-immobilized DNA hybridization studies. J. Am. Chem. Soc. 121:2921-2922.

[8] Feinberg AP, Vogelstein B (1983) A technique for radiolabelling DNA restriction endonuclease fragments to high specific activity. Anal. Biochem. 132: 6-13.

[9] Jablonski E, Moomaw EW, Tullis RH (1986). Preparation of oligonucleotide-alkaline phosphatase conjugates and their use as hybridization probes. Nucl. Acid Res. 14: 61156128.

[10] Langer P, Waldrop AA, Ward DC (1981) Enzymatic synthesis of biotin-labeled polynucleotides: novel nucleic acid affinity probes. Proc. Natl. Acad. Sci. 78: 6633-6637.

[11] Kafatos FC, Jones CW, Efstratiadis A (1979) Determination of nucleic acid sequence homologies and relative concentrations by a dot hybridization procedure. Nucl. Acids Res. 7:1541-52.

[12] Southern EM (1975). Detection of specific sequences among DNA fragments separated by gel electrophoresis. J. Mol. Biol. 98: 503-517.

[13] Alwine JC, Kemp DJ, Stark GR (1977) Method for detection of specific RNAs in agarose gels by transfer to diazobenzyl-oxymethil-paper and hybridization with DNA probes. Proc. Natl. Acad. Sci. USA 74:5350-5354.

[14] Grunstein M, Hogness DS (1975) Colony hybridization: a method for the isolation of cloned DNA's that contain a specific gene. Proc. Natl. Acad. Sci. 72:3961-3965.

[15] Leary JJ, Brigati DJ, Ward DC (1983) Rapid and sensitive colorimetric method for visualizing biotinlabeled DNA probes hybridized to DNA or RNA immobilized on nitrocellulose: Bio-blots. Proc. Natl Acad. Sci. USA, 80:4045-4049.

[16] Achemchem F, Martínez-Bueno M, Abrini J, Valdivia E, Maqueda M (2005) Enterococcus faecium F58, a bacteriocinogenic strain naturally occurring in Jben, a soft, farmhouse goat's cheese made in Morocco. J. Appl. Microbiol. 99:141-150.

[17] Baylis CL (2009) Raw milk and raw milk cheeses as vehicles for infection by Verocytotoxin-producing Escherichia coli. Int. J. Dairy Technol. 62: 293-307.

[18] Bottari DA, Emmett CD, Nichols CE, Whippie KD, Rodriguez D, Durbin GW, Keough KM, Groody EP, Mozola MA, Reynolds GN (1995) Comparative study of a colorimetric DNA hybridization method and conventional culture procedures for the detection of Listeria spp. in foods. J. Food Protect. 58:1083-1090.

[19] Curiale MS, Klatt MJ (1990) Colorimetric deoxyribonucleic acid hybridization assay for rapid screening of Salmonella in food: collaborative study. J. Assoc. Off. Anal. Chem. 73: 248-256.

[20] Datta AR, Wentz BA, Hill WE (1987) Detection of hemolytic Listeria monocytogenes by using DNA colony hybridization. Appl. Environ. Microbiol. 53: 2256-2259.

[21] Flowers RS, Klatt MJ, Mozola MA, Curiale MS, Gabis DA, Silliker JH (1987) DNA hybridization assay for detection of Salmonella in foods: collaborative study. J. Assoc. Off. Anal. Chem. 70:521-9 
[22] Gómez D, Miliwebsky E, Fernández Pascua C, Baschkier A, Manfredi E, Zotta M, Nario F, Piquín A, Sanz M, Etcheverría A, Padola N, Parma A, Rivas M (2002) Isolation and characterization of Shiga-toxin-producing Escherichia coli from frozen hamburgers and soft cheeses. Rev. Argent. Microbiol. 34:66-71.

[23] Mozola M, Halbert D, Chan S, Hsu H-Y, Johnson A, King W, Wilson S, Betts RP, Bankes P, Banks JG (2010) Detection of foodborne bacterial pathogens by a colorimetric DNA hybridization method. In Genetic Manipulation: Techniques and applications (eds J. M. Grange, A. Fox and N. L. Morgan), Blackwell Scientific Publishing, Oxford, UK.

[24] Grunstein M, Hogness DS (1975) Colony hybridization: a method for the isolation of cloned DNA's that contain a specific gene. Proc. Natl. Acad. Sci. 72:3961-3965.

[25] Herman LM, De Block JH, Moermans RJ (1995) Direct detection of Listeria monocytogenes in 25 milliliters of raw milk by a two-step PCR with nested primers. Appl. Environ. Microbiol. 61:817-819

[26] Hill WE, Madden JM, McCardell BA, Shah DB, Jagow JA, Payne WL, Boutin BK (1983) Foodborne enterotoxigenic Escherichia coli: detection and enumeration by DNA colony hybridization. Appl. Environ. Microbiol. 45:1324-1330.

[27] King, W., S. Raposa, J. Warshaw, A. Johnson, D. Halbert, J.D. Klinger (1989) A new colorimetric nucleic acid hybridization assay for Listeria in foods. Int. J. Food Microbiol. 8:225-232

[28] Kneifel W, Manafi M, Breit A (1992) Adaptation of two commercially available DNA probes for the detection of E. coli and Staphylococcus aureus to selected fields of dairy hygiene--an exemplary study. Zentralbl. Hyg. Umweltmed. 192:544-53.

[29] Lira WM, Macedo C, Marin JM (2004) The incidence of Shiga toxin-producing Escherichia coli in cattle with mastitis in Brazil. J. Appl. Microbiol. 97: 861-866.

[30] Madic J, Vingadassalon N, de Garam CP, Marault M, Scheutz F, Brugère H, Jamet E, Auvray F. (2011) Detection of Shiga toxin-producing Escherichia coli serotypes O26:H11, O103:H2, O111:H8, O145:H28, and O157:H7 in raw-milk cheeses by using multiplex real-time PCR. Appl. Environ. Microbiol. 77:2035-41.

[31] Ng LK, Kingombe CI, Yan W, Taylor DE, Hiratsuka K, Malik N, Garcia MM (1997) Specific detection and confirmation of Campylobacter jejuni by DNA hybridization and PCR. Appl. Environ. Microbiol. 63:4558-4563.

[32] O'Connor L, Joy J, Kane M, Smith T, Maher M (2000) Rapid Polymerase Chain Reaction/DNA Probe Membrane-Based Assay for the Detection of Listeria and Listeria monocytogenes in Food. J. Food Protect. 63:337-342.

[33] Padmapriya BP, Ramesh A, Chandrashekar A, Varadaraj MC (2003) Staphylococcal accessory gene regulator (sar) as a signature gene to detect enterotoxigenic staphylococci. J. Appl. Microbiol. 95:974-981.

[34] Pradel N, Bertin Y, Martin C, Livrelli V (2008) Molecular analysis of shiga toxinproducing Escherichia coli strains isolated from hemolytic-uremic syndrome patients and dairy samples in France. Appl. Environ. Microbiol. 74: 2118-2128.

[35] Samadpour M, Liston J, Ongerth JE, Tarr PI (1990) Evaluation of DNA probes for detection of Shiga-like-toxin-producing Escherichia coli in food and calf fecal samples. Appl. Environ. Microbiol. 56: 1212-1215. 
[36] Stevens KA, Jaykus LA (2004) Direct detection of bacterial pathogens in representative dairy products using a combined bacterial concentration-PCR approach. J. Appl. Microbiol. 97:1115-1122.

[37] Vernozy-Rozand C, Mazuy C, Prevost G, Lapeyre C, Bes M, Brun Y, Fleurette J (1996) Enterotoxin production by coagulase-negative staphylococci isolated from goats' milk and cheese. Int. J. Food Microbiol. 30:271-80.

[38] Villard L, Kodjo A, Borges E, Maurin F, Richard Y (2000) Ribotyping and rapid identification of Staphylococcus xylosus by 16-23S spacer amplification. FEMS Microbiol. Lett. 185: 83-87.

[39] Wang G, Clark CG, Taylor TM, Pucknell C, Barton C, Price L, Woodward DL, Rodgers FG (2002) Colony multiplex PCR assay for identification and differentiation of Campylobacter jejuni, C. coli, C. lari, C. upsaliensis, and C. fetus subsp. fetus. J. Clin. Microbiol. 40:4744-4747.

[40] Wesley IV, Wesley RD, Heisick J, Harrell F, Wagner D (1990) Characterization of Listeria monocytogenes isolates by Southern blot hybridization. Vet. Microbiol. 24:341-53.

[41] Zweifel C, Giezendanner N, Corti S, Krause G, Beutin L, Danuser J, Stephan R (2010) Characteristics of Shiga toxin-producing Escherichia coli isolated from Swiss raw milk cheese within a 3-year monitoring program. J. Food Protect. 73: 88-91.

[42] Amann RI, Krumholz L, Stahl DA (1990a). Fluorescent oligonucleotide probing of whole cells for determinative, phylogenetic, and environmental studies in microbiology. J. Bacteriol. 172:762-770.

[43] Amann RI, Binder BJ, Olson RJ, Chisholm SW, Devereux R, Stahl DA (1990b) Combination of $16 \mathrm{~S}$ rRNA-targeted oligonucleotide probes with flow cytometry for analyzing mixed microbial populations. Appl. Environ. Microbiol. 56:1919-1925.

[44] Fuchizawa I, Shimizu S, Kawai Y, Yamazaki K (2008) Specific detection and quantitative enumeration of Listeria spp. using fluorescent in situ hybridization in combination with filter cultivation (FISHFC). J. Appl. Microbiol. 105:502-509.

[45] Gunasekera TS, Veal DA, Attfield PV (2003) Potential for broad applications of flow cytometry and fluorescence techniques in microbiological and somatic cell analyses of milk. Int. J. Food Microbiol. 85:269-279.

[46] Oliveira M, Blasco L, Ferrer S, Bernardo F (2004) Rapid and simultaneous detection of Salmonella spp. and Listeria monocytogenes in milk by Fluorescent In situ Hybridisation. Revista Portuguesa de Ciencias Veterinárias. 99: 215-218.

[47] Schmid M, Walcher M, Bubert A, Wagner M, Wagner M, Schleifer K-H (2003) Nucleic acid-based, cultivation-independent detection of Listeria spp. and genotypes of $L$. monocytogenes. FEMS Immunol. Medical Microbiol. 35: 215-225.

[48] Stender H, Oliveira K, Rigby S, Bargoot F, Coull J (2001) Rapid detection, identification, and enumeration of Escherichia coli by fluorescence in situ hybridization using an array scanner. J. Microbiol. Methods 45:31-39.

[49] Mullis KB, Faloona FA (1987) Specific synthesis of DNA in vitro via a polymerasecatalyzed chain reaction. Meth. Enzimol. 155: 335-350.

[50] Saiki RK, Scharf SJ, Faloona F, Mullis KB, Horn GT, Erlich HA, Arnheim N (1985). Enzymatic amplification of $\beta$-globin genomic sequences and restriction site analysis for diagnosis of sickle cell anemia. Science 230: 1350. 
[51] Mullis KB, Faloona FA, Scharf SJ, Saiki RK, Horn GT, Erlich HA (1986) Specific enzymatic amplification of DNA in vitro: The polymerase chain reaction. Cold Spring Harbor Symp. Quant. Biol. 51:263-273.

[52] Hong Y, Berrang ME, Liu T, Hofacre CL, Sanchez S, Wang L, Maurer JJ (2003) Rapid detection of Campylobacter coli, C. jejuni, and Salmonella enterica on poultry carcasses by using PCR-enzyme-linked immunosorbent assay. Appl. Environ. Microbiol. 69:34923499.

[53] Lazcka O, Del Campo FJ, Munoz FX (2007) Pathogen detection: a perspective of traditional methods and biosensors. Biosensors and bioelectronics 22: 1205-1217.

[54] Aslam M, Hogan J, Smith KL, (2003) Development of a PCR-based assay to detect Shiga toxin-producing Escherichia coli, Listeria monocytogenes, and Salmonella in milk. Food Microbiol. 20:345-350.

[55] Caro I, Garcì-Armesto MR (2007) Occurrence of Shiga toxin-producing Escherichia coli in a Spanish raw ewe's milk cheese. Int. J. Food Microbiol. 116: 410-413.

[56] Caro I, Fernández-Barata VM, Alonso-Llamazares A, García-Armesto MR (2006) Detection, occurrence, and characterization of Escherichia coli O157:H7 from raw ewe's milk in Spain. J. Food Prot. 69:920-4.

[57] El-Sharoud WM, (2009) Prevalence and survival of Campylobacter in Egyptian dairy products. Food Res. Int. 42:622-626.

[58] Fooladi IAA, Naderi THR (2010) Detection of enterotoxigenic Staphylococcus aureus isolates in domestic dairy products. Iranian J. Microbiol. 2:137-142.

[59] Gilbert C, Winters D, O'Leary A, Slavik M (2003) Development of a triplex PCR assay for the specific detection of Campylobacter jejuni, Salmonella spp., and Escherichia coli O157:H7. Mol. Cell Probes 17:135-138.

[60] Herman LMF, De Ridder HFM, Vlaemynck GMM (1995) A multiplex PCR method for the identification of Listeria spp. and Listeria monocytogenes in dairy samples. J. Food Protect. 58:867-872.

[61] Kav K, Col R, Ardic M (2011) Characterization of Staphylococcus aureus isolates from white-brined Urfa cheese. J. Food Prot. 74:1788-96.

[62] Meng J, Zhao S, Doyle MP (1998) Virulence genes of Shiga toxin-producing Escherichia coli isolated from food, animals and humans. Int. J. Food Microbiol. 45: 229-235.

[63] Mora A, León SL, Blanco M, Blanco JE, López C, Dahbi G, Echeita A, González EA, Blanco J (2007) Phage types, virulence genes and PFGE profiles of Shigatoxin-producing Escherichia coli O157:H7 isolated from raw beef, soft cheese and vegetables in Lima (Peru). Int. J. Food Microbiol. 114:204-210.

[64] Peles F, Wagner M, Varga L, Hein I, Rieck P, Gutser K, Kereszturi P, Szabo A (2007) Characterization of Staphylococcus aureus strains isolated from bovine milk in Hungary. Int. J. Food Microbiol. 118:186-193.

[65] Rosengren A, Fabricius A, Guss B, Sylven S, Lindqvist R (2010) Occurrence of foodborne pathogens and characterization of Staphylococcus aureus in cheese produced on farm-dairies. Int. J. Food Microbiol. 144:263-269.

[66] Tamarapu S, McKillip JL, Drake M (2001) Development of a multiplex polymerase chain reaction assay for detection and differentiation of Staphylococcus aureus in dairy products. J. Food Protect. 64:664-668. 
[67] Debruyne L, Samyn E, De Brandt E, Vandenberg O, Heyndrickx M, Vandamme P (2008) Comparative performance of different PCR assays for the identification of Campylobacter jejuni and Campylobacter coli. Res. Microbiol. 159:88-93.

[68] On SLW, Jordan PJ (2003) Evaluation of 11 PCR assays for species-level identification of Campylobacter jejuni and Campylobacter coli. J. Clin. Microbiol. 41:330-336.

[69] On SLW, Brandt SM, Cornelius AJ, Fusco V, Quero GM, Mackie E, Houf K, Bilbao A, Díaz AI , Benejat L, Megraud F, Collins-Emerson J, French NP, Gotcheva V, Angelov A, Alakomi H-L, Saarela M, Paulin SM (2012) PCR revisited: a case for revalidation of pcr assays for microorganisms using identification of Campylobacter species as an exemplar. Qual. Assur. Saf. Crop. (Submitted).

[70] Wang RF, Cao WW, Johnson MG (1992) $16 \mathrm{~S}$ rRNA-based probes and polymerase chain reaction method to detect Listeria monocytogenes cells added to foods. Appl. Environ. Microbiol. 58:2827-2831.

[71] Furrer U, Candrian C, Luethy HJ (1991) Detection and identification of Listeria monocytogenes in cooked sausage products and in milk by in vitro amplification of haemolysin gene fragments J. Appl. Bacteriol. 70:372-379.

[72] Amagliani G, Brandi G, Omiccioli E, Casiere A, Bruce IJ, Magnani M (2004) Direct detection of Listeria monocytogenes from milk by magnetic based DNA isolation and PCR. Food Microbiol. 21: 597-603.

[73] Aznar R, Alarcón B (2003) PCR detection of Listeria monocytogenes: a study of multiple factors affecting sensitivity J. Appl. Microbiol. 95:958-966.

[74] Ercolini D, Fusco V, Blaiotta G, Sarghini F, Coppola S (2005) Response of Escherichia coli O157:H7, Listeria monocytogenes, Salmonella typhimurium, and Staphylococcus aureus to the thermal stress occurring in model manufactures Grana Padano cheese. J. Dairy Sci. 88:3818-3825.

[75] Longhi CA, Maffeo M, Petrone PG, Seganti L, Conte MP (2003) Detection of Listeria monocytogenes in Italian-style soft cheeses. J. Appl. Microbiol. 94: 879-885.

[76] Vanniasinkam T, Lanser JA, Barton MD (1999) PCR for the detection of Campylobacter spp. in clinical specimens Lett. Appl. Microbiol. 28:52-56.

[77] Meng J, Zhao S, Doyle MP, Mitchell SE, Kresovich S (1996) Polymerase chain reaction for detecting Escherichia coli O157: H7. Int. J. Food Microbiol. 32:103-13.

[78] Gooding CM, Choudary PV (1997) Rapid and sensitive immunomagnetic separationpolymerase chain reaction method for the detection of Escherichia coli O157:H7 in raw milk and ice-cream. J. Dairy Res. 64:87-93.

[79] Fusco V, Riccardi M, Quero GM (2012b) TAL method versus MPN-PCR to enumerate viable and stressed E. coli $\mathrm{O} 157: \mathrm{H7}$ and application in a traditional raw milk pasta filata cheese. Int. J. Food Microbiol.

[80] McKillip JL, Jaykus LA, Drake MA (2000) A comparison of methods for the detection of Escherichia coli O157:H7 from artificially-contaminated dairy products using PCR. J. Appl. Microbiol. 89: 49-55.

[81] Ferretti R, Mannazzu I, Cocolin L, Comi G, Clementi F (2001) Twelve-hour PCR-based method for detection of Salmonella spp. in food. Appl. Environ. Microbiol. 67:977-978. 
[82] Houser BA, Donaldson SC, Kehoe SI, Heinrichs AJ, Jayarao BM (2008) A survey of bacteriological quality and the occurrence of Salmonella in raw bovine colostrum. Foodborne Pathog. Dis. 5(6): 853-858.

[83] Khan MA, Kim CH, Kakoma I, Morin E, Hansen RD, Hurley WL, Tripathy DN, Baek BK (1998) Detection of Staphylococcus aureus in milk by use of polymerase chain reaction analysis. Am. J. Vet. Res. 59:807-13.

[84] Blaiotta G, Ercolini D, Pennacchia C, Fusco V, Casaburi A, Pepe O, Villani F (2004) PCR detection of staphylococcal enterotoxin genes in Staphylococcus spp. strains isolated from meat and dairy products. Evidence for new variants of seG and seI in S. aureus AB-8802. J. Appl. Microbiol. 97:719-730.

[85] Boerema JA, Clemens R, Brightwell G (2006) Evaluation of molecular methods to determine enterotoxigenic status and molecular genotype of bovine, ovine, human and food isolates of Staphylococcus aureus. Int. J. Food Microbiol. 107:192 - 201.

[86] Ercolini D, Blaiotta G, Fusco V, Coppola S (2004) PCR-based detection of enterotoxigenic Staphylococcus aureus in the early stages of raw milk cheese making. J. Appl. Microbiol. 96:1090-1096.

[87] Kim CH, Khan M, Morin DE, Hurley WL, Tripathy DN, Kehrli M Jr, Oluoch AO, Kakoma I (2001) Optimization of the PCR for detection of Staphylococcus aureus nuc gene in bovine milk. J. Dairy Sci. 84(1):74-83.

[88] Pinto B, Chenoll E, Aznar R (2005) Identification and typing of food-borne Staphylococcus aureus by PCR-based techniques. Sys. Appl. Microbiol. 28:340-352.

[89] Rosec JP, Gigaud O (2002) Staphylococcal enterotoxin genes of classical and new types detected by PCR in France. Int. J. Food Microbiol. 77: 61-70.

[90] Adwan G, Abu-Shanab B, Adwan K (2005) Enterotoxigenic Staphylococcus aureus in raw milk in the north of Palestine. Turk. J. Biol. 29:229-232.

[91] Arcuri EF, Angelo FF, Guimiraes MFM, Talon R, de Fatima Borges M, Leroy S, Loiseau G, Lange CC, de Andrade NJ, Montet D (2010) Toxigenic status of Staphylococcus aureus isolated from bovine raw milk and minas frescal cheese in Brazil. J. Food Protect. 73:2225-2231.

[92] Argudín MA, Mendoza MC, González-Hevia MA, Bances M, Guerra B,M. R. Rodicio (2012) Genotypes, exotoxin gene content, and antimicrobial resistance of Staphylococcus aureus strains recovered from foods and food handlers. Appl. Environ. Microbiol. 78:2930-2935.

[93] Bartolomeoli I, Maifreni M, Frigo F, Urli G, Marino M (2009) Occurrence and characterization of Staphylococcus aureus isolated from raw milk for cheesemaking. Int. J. Dairy Technol. 62:366-373.

[94] Bendahou A, Abid M, Bouteldoun N, Catelejine D, Lebbadi M (2009) Enterotoxigenic coagulase positive Staphylococcus in milk and milk products, lben and Jben, in northern Morocco. J. Infect. Dev. Ctries. 3:169-176.

[95] Intrakamhaeng M., Komutarin T., Pimpukdee K., Aengwanich W (2012) Incidence of enterotoxin-producing MRSA in bovine mastitis cases, bulk milk tanks and processing plants in Thailand. J. Anim. Vet. Adv. 11:655-661. 
[96] Rall VLM, Vieira FP, Rall R, Vieitis RL, Fernandes Jr A, Candeias JMG, Cardoso KFG, Araujo Jr. JP (2008) PCR detection of staphylococcal enterotoxin genes in Staphylococcus aureus strains isolated from raw and pasteurized milk. Vet. Microbiol. 132:408-413.

[97] Wilson IG, Cooper JE, Gilmour A (1991) Detection of enterotoxigenic Staphylococcus aureus in dried skimmed milk: use of the polymerase chain reaction for amplification and detection of staphylococcal enterotoxin genes entB and entC1 and the thermonuclease gene nuc. Appl. Environ. Microbiol. 57: 1793-1798.

[98] Chiang Y-C, Chang L-T, Lin C-W, Yang C-Y, Tsen H-Y (2006) PCR Primers for the detection of staphylococcal enterotoxins $\mathrm{K}, \mathrm{L}$, and $\mathrm{M}$ and survey of staphylococcal enterotoxin types in Staphylococcus aureus isolates from food poisoning cases in Taiwan. J. Food Protect. 69:1072-1079.

[99] Mantynen V, Niemela S, Kaijalainen S, Pirhonen T, Lindstrom K (1997) MPN-PCRquantification method for staphylococcal enterotoxin $\mathrm{c} 1$ gene from fresh cheese. Int. J. Food Microbiol. 36:135-143.

[100] Blaiotta G, Fusco V, von Eiff C, Villani F, Becker K (2006) Biotyping of enterotoxigenic Staphylococcus aureus by enterotoxin gene cluster $(e g c)$ polymorphism and spa typing analyses. Appl. Environ. Microbiol. 72:6117-23.

[101] Fusco V, Quero GM, Morea M, Blaiotta G, Visconti A (2011a) Rapid and reliable identification of Staphylococcus aureus harbouring the enterotoxin gene cluster $(\mathrm{egc})$ and quantitative detection in raw milk by real time PCR. Int. J. Food Microbiol. 144:528-37.

[102] Akineden Ö, Hassan AA, Schneider E, Usleber E (2008) Enterotoxigenic properties of Staphylococcus aureus isolated from goats' milk cheese. Int. J. Food Microbiol.124:211-216.

[103] Aires-de-Sousa M, Parente CE, Vieira-da-Motta O, Bonna IC, Silva DA, de Lencastre H (2007) Characterization of Staphylococcus aureus isolates from buffalo, bovine, ovine, and caprine milk samples collected in Rio de Janeiro State, Brazil. Appl. Environ. Microbiol. 73:3845-9.

[104] Hwang SY, Park YK, Koo HC, Park YH (2010) spa typing and enterotoxin gene profile of Staphylococcus aureus isolated from bovine raw milk in Korea. J. Vet. Sci. 11:125-131.

[105] Johler S, Layer F, Stephan R (2001) Comparison of virulence and antibiotic resistance genes of food poisoning outbreak isolates of Staphylococcus aureus with isolates obtained from bovine mastitis milk and pig carcasses. J Food Prot.74:1852-9.

[106] Stephan R., Annemuller C., Hassan A.A., Lammler CH (2001) Characterization of enterotoxigenic Staphylococcus aureus strains isolated from bovine mastitis in north-east Switzerland. Vet. Microbiol. 78:373-382.

[107] Mackay IM (2004) Real-time PCR in the microbiology laboratory. Clin. Microbiol. Infect. 10:190-212.

[108] Wilhelm J, Pingoud A (2003) Real -time Polymerase chain reaction. Chem. Bio Chem. 4:1120-1128.

[109] Förster T (1948) Zwischenmolekulare energiewanderung und fluoreszenz. Ann. Phys. 6: 55-75.

[110] Fusco V, Quero GM, Stea G, Morea M, Visconti A (2011b) Novel PCR-based identification of Weissella confusa using an AFLP-derived marker. Int. J. Food Microbiol. 145:437-443. 
[111] Powell HA, Gooding CM, Garrett SD, Lund BM, McKee RA (1994). Proteinase inhibition of the detection of Listeria monocytogenes in milk using the polymerase chain reaction. Lett. Appl. Microbiol. 18:59-61.

[112] Ramesh A, Padmapriya BP, Chandrashekar A, Varadaraj MC (2002) Application of a convenient DNA extraction method and multiplex PCR for the direct detection of Staphylococcus aureus and Yersinia enterocolitica in milk samples. Mol. Cell. Prob. 16:307-314.

[113] Wilson IG (1997) Inhibition and facilitation of nucleic acid amplification. Appl. Environ. Microbiol. 63:3741-3751.

[114] Barkema HW, Schukken YH, Zadoks RN (2006) Invited review: The role of cow, pathogen, and treatment regimen in the therapeutic success of bovine Staphylococcus aureus mastitis. J. Dairy Sci. 89:1877-1895.

[115] Celik HA, Aydin I, Kav K (2009) Identification and antimicrobial susceptibility of subclinical mastitis pathogens isolated from hair goats' milk. J. Anim. Vet. Adv. 8:10861090.

[116] Vanderhaeghen W, Cerpentier T, Adriaensen C, Vicca J, Hermans K, Butaye P (2010) Methicillin-resistant Staphylococcus aureus (MRSA) ST398 associated with clinical and subclinical mastitis in Belgian cows. Vet. Microbiol. 144:166-171.

[117] Asao T, Kumeda Y, Kawai T, Shibata T, Oda H, Haruki K, Nakazawa H, Kozaki S (2003) An extensive outbreak of staphylococcal food poisoning due to low-fat milk in Japan: estimation of enterotoxin A in the incriminated milk and powdered skim milk. Epidemiol Infect. 130:33-40.

[118] De Buyser M-L, Dufour B, Maire M, Lafarge V (2001) Implication of milk and milk products in food-borne diseases in France and in different industrialised countries. Int. J. Food Microbiol. 67: 1-17.

[119] Jørgensen HJ, Mørk T, Rørvik LM (2005) The occurrence of Staphylococcus aureus on a farm with small-scale production of raw milk cheese. J. Dairy Sci. 88:3810-3817.

[120] Lindqvist R, Sylvén S, Vagsholm I (2002) Quantitative microbial risk assessment exemplified by Staphylococcus aureus in unripened cheese made from raw milk. Int. J. Food Microbiol. 78:155-170.

[121] Ostyn A, De Buyser ML, Guillier F, Groult J, Felix B, Salah S, Delmas G, Hennekinne JA (2010) First evidence of a food poisoning outbreak due to staphylococcal enterotoxin type E, France, 2009. Euro Surveill. 15(13) pii: 19528.

[122] Soejima T, Nagao E, Yano Y, Yamagata H, Kagi H, Shinagawa K (2007) Risk evaluation for staphylococcal food poisoning in processed milk produced with skim milk powder. Int. J. Food Microbiol. 115:29-34.

[123] Fusco V, Quero GM, Tempesta B (2012) Culture-dependent and independent TaqMan real time PCR-based identification and quantification of Listeria monocytogenes and its application in raw milk and soft cheese. (Manuscript in preparation).

[124] Nogva HK, Rudi K, Naterstad K, Holck A, Lillehaug D (2000) Application of 5'nuclease PCR for quantitative detection of Listeria monocytogenes in pure cultures, water, skim milk, and unpasteurized whole milk. Appl. Environ. Microbiol. 66:4266.

[125] O'Brien M, Hunt K, McSweeney S, Jordan K (2009) Occurrence of foodborne pathogens in Irish farmhouse cheese. Food Microbiol. 26:910-914. 
[126] O'Grady J, Sedano-Balbas S, Maher M, Smith T, Barry T (2008) Rapid real-time PCR detection of Listeria monocytogenes in enriched food samples based on the ssrA gene, a novel diagnostic target. Food Microbiol. 25:75-84.

[127] O'Grady J, Ruttledge M, Sedano-Balba' s S, Smith TJ, Barry T, Maher M (2009) Rapid detection of Listeria monocytogenes in food using culture enrichment combined with realtime PCR. Food Microbiol. 26:4-7.

[128] D'Agostino M, Wagner M, Vazquez-Boland JA, Kuchta T, Kapriskova R, Hoorfar J, Novella S, Scortti M, Ellison J, Murray A, Fernandes I, Kuhn M, Pazlarova J, Heuvelink A, Cook N (2004) A validated PCR-based method to detect Listeria monocytogenes using raw milk as a food model-towards an international standard. J. Food Prot. 67:1646-1655.

[129] Rossmanith P, Krassnig M, Wagner M, Hein I (2006) Detection of Listeria monocytogenes in food using a combined enrichment/real-time PCR method targeting the prfA gene. Res. Microbiol. 157:763-771.

[130] De Martinis EC, Duvall RE, Hitchins AD. Real-time PCR detection of $16 S$ rRNA genes speeds most-probable-number enumeration of foodborne Listeria monocytogenes. J. Food Prot. 2007 70:1650-5.

[131] Rantsiou K, Alessandria V, Urso R, Dolci P, Cocolin L (2008) Detection, quantification and vitality of Listeria monocytogenes in food as determined by quantitative PCR. Int. J. Food Microbiol. 121:99-105.

[132] Alessandria V, Rantsiou K, Dolci P, Cocolin L (2010) Molecular methods to assess Listeria monocytogenes route of contamination in a dairy processing plant. Int. J. Food Microbiol. 141:S156-S162.

[133] Chiang Y-C, Fan CM, Liao WW, Lin CK, Tsen HY (2007) Real-Time PCR detection of Staphylococcus aureus in milk and meat using new primers designed from the heat shock protein gene htrA sequence. J. Food Protect 70:2855-2859.

[134] Poli A, Guglielmini E, Sembeni S, Spiazzi M, Dellaglio F, Rossi F, Torriani S (2007) Detection of Staphylococcus aureus and enterotoxin genotype diversity in Monte Veronese, a protected designation of origin Italian cheese. Lett. Appl. Microbiol. 45: 529-534.

[135] Ibekwe AM, Watt PM, Grieve CM, Sharma VK, Lyons SR (2002) Multiplex fluorogenic real-time PCR for detection and quantification of Escherichia coli O157:H7 in dairy wastewater Wetlands. Appl. Environ. Microbiol. 68: 4853-4862.

[136] McKillip JL, Drake M (2000) Molecular beacon polymerase chain reaction detection of Escherichia coli O157:H7 in milk. J. Food Protect. 63: 855-859.

[137] Auvray F, Lecureuil C, Dilasser F, Tache' J, Derzelle S (2009) Development of a realtime PCR assay with an internal amplification control for the screening of shiga toxinproducing Escherichia coli in foods. Lett. Appl. Microbiol. 48:554-559.

[138] Yang C, Jiang Y, Huang K, Zhu C, Yin Y (2003) Application of real-time PCR for quantitative detection of Campylobacter jejuni in poultry, milk and environmental water. FEMS Immunol. Med. Microbiol. 38:265-271.

[139] Malorny B, Paccassoni E, Fach P, Bunge C, Martin A, Helmuth R (2004) Diagnostic realtime PCR for detection of Salmonella in food. Appl. Environ. Microbiol. 70: 7046-7052.

[140] Bohaychuk VM, Gensler GE, McFall ME, King RK Renter DG (2007) A Real-Time PCR assay for the detection of Salmonella in a wide variety of food and food-animal matrices. J. Food Protect. 70:1080-1087. 
[141] Paiva de Sousa C (2008) The impact of food manufacturing practices on food borne diseases. Braz. Arch. Biol. Technol. 51: 815-823.

[142] Wu VCH (2008) A review of microbial injury and recovery methods. Food Microbiol. 25:735-744.

[143] Dinu L-D, Bach S (2011) Induction of viable but nonculturable Escherichia coli O157:H7 in the Phyllosphere of lettuce: a food safety risk factor. Appl. Environ. Microbiol. 77: 8295-8302.

[144] House B, Kus JV, Prayitno N, Mair R, Que L, Chingcuanco F, Gannon V, Cvitkovitch DG, Barnett Foster D (2009) Acid-stress-induced changes in enterohaemorrhagic Escherichia coli O157:H7 virulence. Microbiology 155: 2907-2918.

[145] Robinson AL, McKillip J (2010) Biology of Escherichia coli O157:H7 in human health and food safety with enphasis on sublethal injury and detection. 1096-1105. In: Current research, technology and education topics in applied microbiology and microbial biotechnology. Mendez-Vilas A. (Ed.) Formatex.

[146] McKillip JL, Jaykus L-A, Drake M (1999) Nucleic acid persistence in heat-killed Escherichia coli O157:H7 from contaminated skim milk. J. Food Protection. 62: 839-844.

[147] Lu Y, Yang W, Shi L, Li L, Alam MJ, Guo S, Miyoshi S (2009) Specific detection of viable Salmonella cells by an ethidium monoazide-loop mediated isothermal amplification (EMA-LAMP) method. J. Health Sci. 55:820-824.

[148] Nogva HK, Drømtorp SM, Nissen H, Rudi K (2003) Ethidium monoazide for DNAbased differentiation of viable and dead bacteria by 5'-nuclease PCR. BioTechniques. 34:804-813.

[149] Pan Y, Breidt F (2007) Enumeration of viable Listeria monocytogenes cells by real-time PCR with propidium monoazide and ethidium monoazide in the presence of dead cells. Appl. Environ. Microbiol. 73:8028-8031.

[150] Rudi, K., Naterstad, K., Drømtorp, S.M. and Holo, H. (2005), Detection of viable and dead Listeria monocytogenes on gouda-like cheeses by real-time PCR. Lett. Appl. Microbiol. 40: 301-306.

[151] Critzer FJ, Dsouza DH, Golden DA (2008) Transcription analysis of stx1, marA, and eaeA genes in Escherichia coli O157:H7 treated with sodium benzoate. J Food Prot. 71:1469-74.

[152] Gonzalez-Escalona N, Hammack TS, Russell M, Jacobson AP, De Jesus AJ, Brown EW, Lampel KA (2009) Detection of live Salmonella sp. cells in produce by a TaqMan-based quantitative reverse transcriptase real-time PCR targeting invA mRNA. Appl. Environ. Microbiol. 75:3714-3720.

[153] Hanna SE, Wang HH (2006) Assessment of environmental factors on Listeria monocytogenes Scott A inlA gene expression by relative quantitative Taqman real-time reverse transcriptase PCR. J. Food Prot. 69:2754-2757.

[154] Lin S, Gilpin B, Scholes P, Podivinsky E, Klena J, Savill M (2009) Preliminary development and validation of a real-time reverse transcription PCR assay for the semiquantification of viable Campylobacter jejuni in water samples. Water Sci. Technol. 60:3151-8.

[155] Wada M, Lkhagvadorj E, Bian L, Wang C, Chiba Y, Nagata S, Shimizu T, Yamashiro Y, Asahara T, Nomoto K (2010) Quantitative reverse transcription-PCR assay for the rapid detection of methicillin-resistant Staphylococcus aureus. J. Appl. Microbiol. 108:779-88. 
[156] Compton J (1991) Nucleic acid sequence-based amplification. Nature 350: 91-2.

[157] Blais BW, Turner G, Sooknanan R, Malek LT (1997) A nucleic acid sequence-based amplification system for detection of Listeria monocytogenes hlyA sequences. Appl. Environ. Microbiol. 63: 310-313.

[158] Cools I, Uyttendaele M, D'Haese E, Nelis HJ, Debevere J (2006) Development of a realtime NASBA assay for the detection of Campylobacter jejuni cells. J. Microbiol. Methods. 66: 313-320.

[159] Simpkins SA, Chan AB, Hays J, Pöpping B, Cook N (2000) An RNA transcriptionbased amplification technique (NASBA) for the detection of viable Salmonella enterica. Lett. Appl. Microbiol. 30:75-9.

[160] Buck RP (2000) Bioanalytic Sensors. In: The biomedical engineering handbook: Second Edition. Ed. Joseph D. Bronzino Boca Raton: CRC Press LLC.

[161] Rasooly A, Herold KE. (2006) Biosensors for the analysis of food- and waterborne pathogens and their toxins. J. AOAC Int. 89:873-883.

[162] Anderson GP, Taitt CR(2008) Amplification of microsphere-based microarrays using catalyzed reporter deposition. Biosen. Bioelectron. 24:324-328.

[163] Deisingh AK, Thompson M (2004) Biosensors for the detection of bacteria. Can. J. Microbiol. 50:69-77(9).

[164] Lui C, Cady NC, Batt CA (2009) Nucleic acid-based detection of bacterial pathogens using integrated microfluidic platform systems. Sensors 9: 3713-3.

[165] Mello LD, Kubota LT (2002) Review of the use of biosensors as analytical tools in the food and drink industries Food Chem. 77:237-256.

[166] Rodriguez-Mozaz S, Marco MP, Lopez de Alda MJ, Barceló D (2004) Biosensors for environmental applications: future development trends. Pure Appl. Chem. 76:723-752.

[167] Hahn S, Mergenthaler S, Zimmermann B, Holzgreve W (2005) Nucleic acid based biosensors: the desires of the user. Bioelectrochemistry. 67:151-154.

[168] Junhui Z, Hong C, Ruifu Y (1997) DNA based biosensors. Biotechnology advances.15:43-58.

[169] Cady NC (2005) Nucleic acid-based biosensing. Ph.D. dissertation. Cornell University, Ithaca, NY, USA.

[170] Liu-Stratton Y, Roy S, Sen CK (2004) DNA microarray technology in nutraceutical and food safety. Toxicol. Lett. 150:29-42.

[171] Cao B, Li R, Xiong S, Yao F, Liu X, Wang M, Feng L, Wang L (2011) Use of a DNA microarray for detection and identification of bacterial pathogens associated with fishery products. Appl. Environ. Microbiol. 77:8219-25.

[172] Donhauser SC, Niessner R, Seidel M (2011) Sensitive quantification of Escherichia coli O157:H7, Salmonella enterica, and Campylobacter jejuni by combining stopped polymerase chain reaction with chemiluminescence flow-through DNA microarray analysis. Anal. Chem. Apr 15;83(8):3153-60. Epub 2011 Mar 21.

[173] Fox EM, Leonard N, Jordan K (2011) Physiological and transcriptional characterization of persistent and nonpersistent Listeria monocytogenes isolates. Appl. Environ. Microbiol. 77:6559-69.

[174] Garneau P, Labrecque O, Maynard C, Messier S, Masson L, Archambault M, Harel J (2010) Use of a bacterial antimicrobial resistance gene microarray for the identification of resistant Staphylococcus aureus. Zoonoses Public Health. 57:94-99. 
[175] Grønlund H, Riber L, Vigre H, Löfström C, Folling L, Huehn S, Malorny B, Rådström P, Rudi K, Hoorfar J (2011) Microarray-based genotyping of Salmonella: inter-laboratory evaluation of reproducibility and standardization potential. Int. J. Food Microbiol. 145 Suppl 1:S79-85.

[176] Koyuncu S, Andersson G, Vos P, Häggblom P (2011) DNA microarray for tracing Salmonella in the feed chain. Int. J. Food Microbiol. 145 Suppl 1:S18-22.

[177] Rodin S, Andersson AF, Wirta V, Eriksson L, Ljungström M, Björkholm B, Lindmark H, Engstrand L (2008) Performance of a 70-mer oligonucleotide microarray for genotyping of Campylobacter jejuni. BMC Microbiol. 8:73.

[178] Salehi TZ, Tonelli A, Mazza A, Staji H, Badagliacca P, Tamai IA, Jamshidi R, Harel J, Lelli R, Masson L (2011) Genetic characterization of Escherichia coli O157:H7 strains isolated from the one-humped camel (Camelus dromedarius) by using microarray DNA technology. Mol Biotechnol. [Epub ahead of print].

[179] Spence RP, Wright V, Ala-Aldeen DA, Turner DP, Wooldridge KG, James R (2008) Validation of virulence and epidemiology DNA microarray for identification and characterization of Staphylococcus aureus isolates. J. Clin. Microbiol. 46:1620-7.

[180] Khandurina J, Guttman A (2002) Bioanalysis in microfluidic devices. J. Chromatog. A. 943:159-183.

[181] Auroux P-A, Koc Y, deMello A, Manz A, Day PJR (2004) Miniaturised nucleic acid analysis. Lab Chip. 4:534-546.

[182] Bashir R (2004) BioMEMS: state-of-the-art in detection, opportunities and prospects. Adv. Drug Deliver. Rev. 56:1565-1596.

[183] Bhattacharya S, Salamat S, Morisette D, Banada P, Akin D, Liu YS, Bhunia AK, Ladisch M, Bashir R (2008) PCR-based detection in a micro-fabricated platform. Lab. Chip. 8:1130-6.

[184] Cady NC, Stelick S, Kunnavakkam MV, Batt CA (2005) Real-time PCR detection of Listeria monocytogenes using an integrated microfluidic platform. Sensor. Actuat. BChem. 107:332-341.

[185] Cady NC, Stelick S, Batt CA (2003) Nucleic acid purification using microfabricated silicon structures. Biosens. Bioelectron. 19:59-66.

[186] Fusco V, Cady NC, Stelick S, Batt CA (2006) Real Time PCR detection of Staphylococcus aureus using a microfluidics biosensor module. FoodMicro 2006 food safety and food biotechnology: diversity and global impact. 29/8-2/9 2006, Bologna, Italy. Page 397.

[187] Van Belkum A, Tassios PT, Dijkshoorn L, Haeggman S, Cookson B, Fry NK, Fussing V, Green J, Feil E, Gerner-Smidt P, Brisse S, Struelens M. and for the European Society of Clinical Microbiology and Infectious Diseases (ESCMID) Study group on epidemiological markers (ESGEM) (2007) Guidelines for the validation and application of typing methods for use in bacterial epidemiology. Clin. Microbiol. Infect. 13: 1-46.

[188] Van Belkum A, Scherer S, van Alphen L, Verbrugh H (1998a) Short-Sequence DNA Repeats in Prokaryotic genomes. Microbiol. Mol. Biol. Rev. 62: 275-293.

[189] Welsh J, McClelland M (1990) Fingerprinting genomes using PCR with arbitrary primers. Nucleic Acid Res. 25: 7212-7218.

[190] van Belkum A, Sluijuter M, de Groot R, Verbrugh H, Hermans PWJ (1996) Novel BOX repeat PCR assay for high-resolution typing of Streptococcus pneumoniae strains. Clin. Microbiol. May 1996 34: 1176-1179. 
[191] Versalovic J, Koeuth T, Lupski JR (1991) Distribution of repetitive DNA sequences in eubacteria and application to fingerprinting of bacterial genomes. Nucleic Acids Res. 19:6823-6831.

[192] Versalovic J, Schneider M, De Bruijn FJ, Lupski JR (1994) Genomic fingerprinting of bacteria using repetitive sequence-based polymerase chain reaction Methods in Molecular and Cellular Biology. Methods Mol. Cell. Biol. 5: 25-40.

[193] Grimont F, Grimont PAD (1986). Ribosomal ribonucleic acid gene restriction patterns as potential taxonomic tools. Ann. Inst. Pasteur Microbiol. 137B: 165-175.

[194] Grif K, Dierich MP, Much P, Hofer E, Allerberger F (2003) Identifying and subtyping species of dangerous pathogens by automated ribotyping. Diagn. Microbiol. Infect. Dis. 47:313-20.

[195] Arimi SM, Ryser E, Pritchard T, Donnelly CW (1997) Diversity of Listeria ribotypes recovered from dairy cattle, silage, and dairy processing environments J. Food Protect. 60:811-816.

[196] Dalton CB, Austin CC, Sobel J, Hayes PS, Bibb WF, Graves LM, Swaminathan B, Proctor ME, Griffin PM (1997) An outbreak of gastroenteritis and fever due to Listeria monocytogenes in milk. N. Engl J. Med. 336:100-106.

[197] Dogan B, Boor KJ (2003) Genetic diversity and spoilage potentials among Pseudomonas spp. isolated from fluid milk products and dairy processing plants. Appl. Environ. Microbiol. 69:130-138.

[198] Kabuki D.Y., Kuaye A.Y., Wiedmann M., Boor K.J. (2004) Molecular subtyping and tracking of Listeria monocytogenes in Latin-style fresh-cheese processing plants. J. Dairy Sci. 87 (9) , pp. 2803-2812.

[199] MacDonald PDM, Whitwam RE, Boggs JD, MacCormack JN, Anderson KL, Reardon JW, Saah JR, Graves LM, Hunter SB, Sobel J (2005) Outbreak of listeriosis among mexican immigrants as a result of consumption of illicitly produced mexican-style cheese. Clin. Infect. Dis. 40: 677-682.

[200] Manfreda G, De Cesare A, Stella S, Cozzi M, Cantoni C (2005) Occurrence and ribotypes of Listeria monocytogenes in Gorgonzola cheeses. Int. J. Food Microbiol. 102:287-293.

[201] Buzzola FRL, Quelle MI, Gomez M, Catalano L, Steele-Moore D, Berg E, Gentilini G, Denamiel G, Sordelli Do (2001) Genotypic analysis of Staphylococcus aureus from milk of dairy cows with mastitis in Argentina. Epidemiol. Infect. 126:445-452.

[202] Hennekinne JA, Kerouanton A, Brisabois A, De Buyser ML (2003) Discrimination of Staphylococcus aureus biotypes by pulsed-field gel electrophoresis of DNA macrorestriction fragments. J. Appl. Microbiol. 94: 321-329.

[203] Hahm B-K, Maldonado Y, Schreiber E, Bhunia AK, Nakatsu CH (2003) Subtyping of foodborne and environmental isolates of Escherichia coli by multiplex-PCR, rep-PCR, PFGE, ribotyping and AFLP. J. Microbiol. Methods 53:387-399.

[204] Pradel N, Bertin Y, Martin C, Livrelli V (2008) Molecular analysis of shiga toxinproducing Escherichia coli strains isolated from hemolytic-uremic syndrome patients and dairy samples in France. Appl. Environ. Microbiol. 74:2118-28.

[205] Nastasi A, Mammina C, Sacco C (2000) Epidemiology of Salmonella bongori 48:z35:- in Southern Italy, 1984-2000. J. Prev. Med. Hyg. 41: 31-33. 
[206] Gibson JR, Fitzgerald C, Owen RJ (1995) Comparison of PFGE, ribotyping and phagetyping in the epidemiological analysis of Campylobacter jejuni serotype HS2 infections. Epidemiol. Infect. 115:215-225.

[207] Patton CM, Wachsmuth IK, Evins GM, Kiehlbauch JA, Plikaytis BD, Troup N, Tompkins L, Lior H (1991) Evaluation of 10 methods to distinguish epidemic-associated Campylobacter strains. J. Clin. Microbiol. 29:680-688.

[208] Vaneechoutte M, Rossau R, De Vos P, Gillis M, Janssens D, Paepe N, De Rouck A, Fiers T, Claeys G, Kersters K (1992) Rapid identification of bacteria of the Comamonadaceae with amplified ribosomal DNA-restriction analysis (ARDRA). FEMS Microbiol Lett. 72:227-33.

[209] Wichelhaus TA, Hunfeld KP, Boddinghaus B, Kraiczy P, Schafer V, Brade V (2001) Rapid molecular typing of methicillin resistant Staphylococcus aureus by PCR-RFLP. Infect. Control Hosp. Epidemiol. 22:294-8.

[210] Harvey J, Gilmour A (1992) Occurrence of Listeria species in raw milk and dairy products produced in Northern Ireland. J Appl Bacteriol. 72:119-25.

[211] Harvey J, Gilmour A (1994) Application of multilocus enzyme electrophoresis and restriction fragment length polymorphism analysis to the typing of Listeria monocytogenes strains isolated from raw milk, nondairy foods, and clinical and veterinary sources. Appl. Environ. Microbiol. 60:1547-53.

[212] Waak E, Tham W, Danielsson-Tham M-L (2002) Prevalence and fingerprinting of Listeria monocytogenes strains isolated from raw whole milk in farm bulk tanks and in dairy plant receiving tanks. Appl. Environ. Microbiol. 68: 3366-3370.

[213] Beutin L, Miko A, Krause G, Pries K, Haby S, Steege K, Albrecht N (2007) Identification of human-pathogenic strains of shiga toxin-producing Escherichia coli from food by a combination of serotyping and molecular typing of Shiga toxin genes. Appl. Environ. Microbiol. 73:4769-4775.

[214] Dauga C, Zabrovskaia A, Grimont PA (1998) Restriction fragment lenght polymorphism analysis of some flagellin genes of Salmonella enterica. J. Clin. Microbiol. 36: 2835-2843.

[215] Kwon HJ, Park KY, Yoo HS, Park JY, Park YH, Kim SJ (2000) Differentiation of Salmonella enterica serotype gallinarum biotype pullorum from biotype gallinarum by analysis of phase 1 flagellin C gene fliC. J. Microbiol. Methods 40:33-38.

[216] Nielsen EM, Engberg J, Fussing V, Petersen L, Brogren CH, On SL (2000) Evaluation of phenotypic and genotypic methods for subtyping Campylobacter jejuni isolates from humans, poultry, and cattle. J. Clin. Microbiol. 38: 3800-3810.

[217] Kawasaki S, Fratamico PM, Wesley IV, Kawamoto S (2008) Species-specific identification of Campylobacters by PCR-Restriction Fragment Length Polymorphism and PCR targeting of the gyrase B gene. Appl. Environ. Microbiol. 2529-2533.

[218] Van Belkum A, van Leeuwen W, Kaufmann ME, Cookson B, Forey F, Etienne J, Goering R, Tenover F, Steward C, O'Brein F, Grubb W, Tassios P, Legakis N, Morvan A, El Solh N, de Ryck R, Struelens M, Salmenlinna S, Vuopio-Varkila J, Kooistra M, Talens A, Witte W, Verbrugh H (1998b) Assessment of resolution and intercenter reproducibility of results of genotyping Staphylococcus aureus by pulsed-field gel electrophoresis of SmaI macrorestriction fragments: a multicenter study. J. Clin. Microbiol. 36:1653-1659. 
[219] Kathariou S (2003) Foodborne outbreaks of listeriosis and epidemic-associated lineages of Listeria monocytogenes. In: Microbial food safety in animal agriculture: current topics. 243-256.

[220] Swaminthan B, Barrett TJ, Hunter SB, Tauxe RV, Force CPT (2001) PulseNet: the molecular subtyping network for bacterial disease surveillance, United States. Emerg. Infect. Dis. 7: 382-389.

[221] Janssen P, Coopman R, Huys G, Swings J, Bleeker M., Vos P, Zabeau M, Kersters K (1996). Evaluation of the DNA fingerprinting method AFLP as a new tool in bacterial taxonomy. Microbiology 142:1881-1893.

[222] Vos P, Hogers R, Bleeker M, Reijans M, Van de Lee T, Hornes M, Frijters A, Pot J, Peleman J, Kuiper M, Zabeau M (1995) AFLP: a new technique for DNA fingerprinting. Nucl. Ac. Res. 21:4407-4414.

[223] Zhao S, Mitchell SE, Meng J, Kresovich S, Doyle MP, Dean RE, Casa AM, Weller JW (2000) Genomic typing of Escherichia coli O157:H7 by semi-automated fluorescent AFLP analysis. Microbes Infect. 2:107-113.

[224] Aarts HJM, Hakemulder LE, Van Hoef AMA (1999) Genomic typing of Listeria monocytogenes strains by automated laser fluorescence analysis of amplified fragment length polymorphism fingerprint patterns. Int. J. Food Microbiol. 49: 95-102.

[225] Lindstedt BA, Heir E, Vardund T, Kapperud G (2000) Fluorescent amplified-fragment length polymorphism genotyping of Salmonella enterica subsp. enterica serovars and comparison with pulsed-field gel electrophoresis typing. J. Clin. Microbiol. 4:1623-1627.

[226] Lomonaco S, Nucera D, Parisi A, Normanno G, Bottero MT (2011) Comparison of two AFLP methods and PFGE using strains of Listeria monocytogenes isolated from environmental and food samples obtained from Piedmont, Italy. Int. J. Food Microbiol. 149:177-182.

[227] Tamada Y, Nakaoka Y, Nishimori K, Doi A, Kumaki T, Uemura N, Tanaka K, Makino SI, Sameshima T, Akiba M, Nakazawa M, Uchida I (2001) Molecular typing and epidemiological study of Salmonella enterica serotype Typhimurium isolates from cattle by fluorescent amplified-fragment length polymorphism fingerprinting and pulsedfield gel electrophoresis. J. Clin. Microbiol. 39:1057-1066.

[228] Tsai TY, Luo WC, Wu FT, Pan TM (2005) Molecular subtyping for Escherichia coli O157: H7 isolated in Taiwan. Microbiol. Immunol. 49:579-88.

[229] Maiden MCJ, Bygraves JA, Feil E, Morelli G, Russell JE, Urwin R, Zhang Q, Zhou J, Zurth K, Caugant DA, Feavers IM, Achtman M, Spratt BG (1998) Multilocus sequence typing: a portable approach to the identification of clones within populations of pathogenic microorganisms. Proc. Natl. Acad. Sci. USA 95:3140-3145.

[230] Maiden MC (2006) Multilocus sequence typing of bacteria. Annu. Rev. Microbiol. 60:561-88.

[231] Zhang W, Jayarao BM, Knabel SJ (2004) Multi-virulence-locus sequence typing of Listeria monocytogenes. Appl. Environ. Microbiol. 70: 913-920. 